\title{
Glutamatergic Inhibition of Voltage-Operated Calcium Channels in the Avian Cochlear Nucleus
}

\author{
E. A. Lachica, R. Rübsamen, ${ }^{\mathrm{a}}$ L. Zirpel, ${ }^{\mathrm{b}}$ and Edwin W Rubel \\ Department of Otolaryngology-Head and Neck Surgery, The Virginia Merrill Bloedel Hearing Research Center, \\ University of Washington, Seattle, Washington 98195
}

The auditory nerve serves as the only excitatory input to neurons in the avian cochlear nucleus, nucleus magnocellularis (NM). NM neurons in immature animals are dependent upon auditory nerve signals; when deprived of them, many NM neurons die, and the rest atrophy. Auditory nerve terminals release glutamate, which can stimulate second messenger systems by activating a metabotropic glutamate receptor (mGluR). Therefore, it is possible that the effectors of mGluR-stimulated signal transduction systems are needed for NM neuronal survival. This study shows that mGluR activation in NM neurons attenuates voltage-dependent changes in $\left[\mathrm{Ca}^{2+}\right]_{i}$. Voltage-dependent $\mathrm{Ca}^{2+}$ influx was also attenuated by increasing CAMP with forskolin, VIP, or 8-bromo-cAMP, indicating that mGluR activation may stimulate adenylate cyclase. The main results may be summarized as follows. NM neurons possess high voltage-activated $\mathrm{Ca}^{2+}$ channels that were modulated by quisqualate, glutamate, and $( \pm)$ trans-ACPD, in that order of potency. Glutamatergic inhibition of $\mathrm{Ca}^{2+}$ influx was not blocked by L-AP3 or L-AP4, which antagonize the actions of mGluRs in other neural systems; it was blocked by serine- $O$-phosphate. Finally, the attenuation of voltage-dependent $\mathrm{Ca}^{2+}$ influx was duplicated by CAMP accumulators. Since NM neurons have high rates of spontaneous activity and higher rates of driven activity, the expression of this mGluR turns out to be very valuable: without it, $\left[\mathrm{Ca}^{2+}\right]_{i}$ could reach lethal concentrations. These results provide an important clue as to the identity of an intracellular signal that may play an important role in NM neuronal survival.

[Key words: deafferentation, excitatory amino acid receptors, neuroprotection, cAMP, auditory system, metabotropic receptor]

In mammals and birds, removal of the membranous cochlea abolishes auditory nerve activity. This initiates a cascade of events which, in young animals, culminates in transneuronal death and atrophy of neurons in the cochlear nucleus. The cel-

\footnotetext{
Received June 29 1994; revised Aug. 26, 1994; accepted Aug. 30, 1994

We thank Dr. Steven Barger for helpful discussion, Drs. Neil Nathanson and Bruce Tempel for critically reading the manuscript, and Mark Walter for his assistance in preparing the illustrations. The work was supported by DC00395 to E.WR., by DC00040 to E.A.L., and the Deutsche Forschungsgemeinschaft. Correspondence should be addressed to $\mathrm{E}$. W Rubel at the above address.

aPresent address: The Zoological Department of the University of I eipzig, Development and Neurobiology Laboratory, Talstrasse 33, D-04103 Leipzig, Germany.

'Present address: Department of Physiology and Biophysics, SJ-40, University of Washington, Seattle, WA.

Copyright (C) 1995 Society for Neuroscience $0270-6474 / 95 / 151724-11 \$ 05.00 / 0$
}

lular events underlying these changes have been most thoroughly studied in nucleus magnocellularis (NM) of the neonatal chicken (see Rubel et al., 1990, for review). Accordingly, it has been postulated that auditory nerve axons provide NM neurons with signals required for neural information processing, and signals that facilitate, promote, or are essential to neuronal survival. Physical contact of the eighth nerve terminal on NM neurons does not promote neuronal survival since degenerative changes are seen when action potentials of the auditory nerve are eliminated by intralabyrinthine application of the sodium channel blocker tetrodotoxin (Born and Rubel, 1988; Pasic and Rubel, 1989). These results indicate that an intraccllular process associated with the excitation of NM neurons is required. However, activity per se is not sufficient: antidromic stimulation of NM neurons or stimulation of eighth nerve axons in a $\mathrm{Ca}^{2+} / \mathrm{Mg}^{2+}$. free environment (eliminating postsynaptic activation of $\mathrm{NM}$ neurons) does not prevent degenerative changes from occurring (Hyson and Rubel, 1989). Degenerative changes are not seen in orthodromically stimulated neurons, however, indicating that this activity-dependent trophic process is dependent upon a presynaptically relcased agent. The excitatory amino acid (EAA), glutamate, is believed to be released from auditory nerve terminals, acting as an excitatory transmitter at the eighth nerve-NM neuron synapse (Nemeth et al., 1983; Raman and Trussell, 1992; Zhou and Parks, 1992). In the present study, we show that glutamate stimulates a second-messenger system in NM neurons whose effectors prevent lethal concentrations of $\mathrm{Ca}^{2+}$ from accumulating.

In addition to stimulating ionotropic receptors (iGluRs) involved in generating EPSPs, glutamate activates metabotropic glutamate receptors (mGluR) that stimulate signal transduction pathways. As a result, mGluRs are capable of altering cell physiology (Desai and Conn, 1991; Lovinger, 1991; Glaum et al., 1992; Collins, 1993), ion channels (Bleakman et al., 1992; Glaum and Miller, 1992, 1993; Kelso et al., 1992; Kinney and Slater, 1993; Sahara and Westbrook, 1993), and neuronal responses to potentially toxic events (Chiamulera et al., 1992; Optiz and Reymann, 1993; Pizzi et al., 1993). In the course of examining the role of glutamate release and its actions on intracellular $\mathrm{Ca}^{2+}$ responses of NM neurons (Zirpel et al., 1994b), it was discovered that glutamate activates a mGluR that inhibits the influx of $\mathrm{Ca}^{2+}$ in depolarized neurons. The EAA agonists kainate and AMPA do not mimic this effect; however, quisqualate, a nonspecific mGluR agonist, and \pm trans-ACPD ( $t$ ACPD), a specific mGluR agonist, do impede $\mathrm{Ca}^{2+}$ influx. This study describes this effect and one of the potential intracellular signals that may regulate it. The results are consistent with the 
hypothesis that activation of this mGluR in NM neurons prevents toxic concentrations of $\mathrm{Ca}^{2+}$ from accumulating. Thus, the products of mGluR stimulation may be essential to the survival of NM neurons, and the absence of these products may initiate or contribute to the degenerative changes observed following deafferentation.

\section{Materials and Methods}

Tissue preparation. White leghorn chicken embryos, 17-18 d old (E17E18), were removed from their shells and staged according to the criteria of Hamburger and Hamilton (1951). The embryo was decapitated and its cerebellum was removed via gross transection of the cerebellar peduncles. The exposed brainstem was blocked rostrally at the level of the motor nucleus of the trigeminal nerve and caudally at the level of the glossopharyngeal nucleus. This block was removed and immersed in $5 \%$ low melting point agarose dissolved in Geys buffer. A square block containing the brainstem was cut out after the agarose solidified, glued onto a metal stage, and cut with a vibratome. A total of $3 \mathrm{~min}$ typically elapsed between the time the embryo was decapitated and the first vibratome section was made.

Coronal sections, $300 \mu \mathrm{m}$ thick, were cut into cold, oxygenated artificial cerebrospinal fluid (aCSF). The aCSF was composed of $125 \mathrm{~mm}$ $\mathrm{NaCl}, 5 \mathrm{mM} \mathrm{KCl}, 1.25 \mathrm{mM} \mathrm{KH} \mathrm{PO}_{4}, 1.3 \mathrm{~mm} \mathrm{MgCl}_{2}, 26 \mathrm{~mm}$ sodium bicarbonate, $10 \mathrm{~mm}$ dextrose, and $3.1 \mathrm{~mm} \mathrm{CaCl}$. A pair of sections containing the rostral one-half of NM were dissected free of agarose, choroid plexus, and meninges and transferred to an aCSF solution containing $5 \mu \mathrm{M}$ fura-2 acetoxymethyl ester (Fura-2), $0.1 \%$ dimethylsulfoxide, and $0.02 \%$ pluronic acid. The slices remained in this solution, oxygenated, and warmed to $37^{\circ} \mathrm{C}$ for 20 to $35 \mathrm{~min}$, at which point they were rinsed in oxygenated aCSF for $10 \mathrm{~min}$ as they were being prepared for imaging. Only one slice was examined per animal, and this slice was not exposed to more than one type of glutamate agonist. This strategy was adopted to prevent confounding results caused by the activation of a second-messenger system stimulated by one agonist that might alter the $\mathrm{Ca}^{2+}$ responses of a second agonist. A single experiment was replicated at least three times, and a single slice from a single animal was used for each experiment.

Microfluorometry. Fura-2 loaded NM cells were alternately illuminated with $340 \mathrm{~nm}$ and $380 \mathrm{~nm}$ wavelengths from a xenon source (Osram). Excitation wavelengths were obtained using interference filters from Chroma Technology (Brattleboro, VT). Emitted light was passed through a $40 \times$ fluor oil immersion objective (Nikon) attached to a $\mathrm{Ni}$ kon Diaphot inverted microscope, through a $480 \mathrm{~nm}$ long-pass exit filter, and finally into an image intensifier coupled to a CCD camera (Hamamatsu, Japan). Cells were exposed to UV light, attenuated to $3 \%$ its normal intensity by neutral density filters, during data collection periods only. Exposure time for each wavelength was between 500 to $750 \mathrm{msec}$, using a computer-controlled shutter and filter wheel (Sutter Inst., Novato, CA). Paired images were captured every $3 \mathrm{sec}$. Data were obtained by comparing the intensity of fluorescent emission to $340 \mathrm{~nm}$ and 380 $\mathrm{nm}$ excitation wavelengths. The difference in emitted fluorescence was expressed as a ratio (F340:F380) that was compared to a standard curve for free $\mathrm{Ca}^{2+}$ constructed from solutions of known $\mathrm{Ca}^{2+}$ and fura-2 concentrations. As a result, ratios of fluorescent intensity were translated directly to $\mathrm{Ca}^{2+}$ concentrations using software designed by Universal Imaging Corp. (West Chester, PA). The $K_{d}$ of hydrolyzed fura- 2 for $\mathrm{Ca}^{2+}$ was calculated as 224 nм (Grynkiewicz et al., 1985). Numerical values reported are an average of $>50$ adjacent pixels.

Pharmaceuticals. The Results section is composed of three components. The first describes the $\mathrm{Ca}^{2+}$ response evoked by depolarizations using $60 \mathrm{mM} \mathrm{KCl}$, and shows that NM neurons possess L-type $\mathrm{Ca}^{2+}$ channels, but not $\mathrm{N}$-type channels. The dihydropyridines, BAY K 8644 , and nifedipine were used to test for the presence of L-channels, and omega-conotoxin GVIA ( $\omega$-CgTX) was used to test for $\mathrm{N}$-channels.

The next segment of the Results describes the effects that glutamate and its analogs have on voltage-dependent $\mathrm{Ca}^{2+}$ influx. The glutamate analogs kainate and alpha-amino-3-hydroxyl-5-methylisoxazole-4-propionic acid (AMPA) were tested, as were the nonspecific and specific mGluR-agonists quisqualate (QA) and \pm trans 1 -amino- 1,3 cyclopentanedicarboxylic acid ( $t$-ACPD), respectively. The actions of glutamate on voltage-dependent $\mathrm{Ca}^{2+}$ influx were challenged by 6 cyano-7-dinitroquinoxaline-2,3 dione (CNQX), an antagonist of non-NMDA-type glutamate receptors, as well as $\mathrm{L}(+)$-2-amino-3-phosphonopropionate (L-AP3), ( \pm )-2-amino-4-phosphonobutyric acid (L-AP4), and L-serine-
$O$-phosphate (SOP), which have all heen shown to block the actions of mGluRs in other neural systems.

The final segment describes the effects that accumulators of cAMP had on voltage-dependent $\mathrm{Ca}^{2+}$ influx. Specifically, NM neurons were exposed to forskolin and vasoactive intestinal peptide (VIP), accumulators of adenylate cyclase; a membrane permeable analog of cAMP, 8-bronu-adenosine cyclic 3',5'-hydrogen phosphate monosodium salt (8-Br-cAMP); and a pair of phosphodiesterase inhibitors, 4-[(3-butoxy4-methoxyphenyl)methyl]-2-imidazolidinone (Ro 20-1724), and 3-isobutyl-1-methylxanthine (IBMX). Neurons were also exposed to a protein kinase $\mathrm{C}$ (PKC) activator, phorbol 12-myristate 13-acetate (PMA).

With a few exceptions, drugs were first dissolved as 200 to $1000 \times$ stock solutions and frozen at $-40^{\circ} \mathrm{C}$ or at $-70^{\circ} \mathrm{C}$ until use. Stock solutions were all dissolved in water, with the following exceptions: BAY-K 8644 was dissolved in methanol; I-AP4, forskolin, IBMX and Ro 20-1724 were dissolved in ethanol; nifedipine, CNQX, and PMA were dissolved in dimethylsulfoxide. Working solutions of $t$-ACPD, L-AP3, L- AP4, and SOP were freshly prepared for each experiment. Solutions of aCSF and glutamate were also prepared daily.

Drug application. A brainstem slice containing NM was placed in Leiden-type microscope-stage chamber, and anchored to the floor of the chamber with a custom-made stainless steel net. A $1 \mathrm{~mm}$ thick, $25 \mathrm{~mm}$ diameter coverglass served as the floor of the chamber, creating a 10 $\mathrm{mm}$ deep reservoir. A stainless steel capillary inlet tube $(1 \mathrm{~mm}$ i.d.) was located $1 \mathrm{~mm}$ above the slice, while the capillary tube connected to a vacuum pump rested on the reservoir floor. The slice was continually perfused in aCSF. The fluid volume in the reservoir when it contained a slice was estimated to be $250 \mu \mathrm{l}$, and the laminar flow rate of the gravity-delivered perfusion system was $3 \mathrm{ml} / \mathrm{min}$. The tubing connecting the $60 \mathrm{cc}$ media reservoirs to the recording chamber was approximately $30 \mathrm{~cm}$ long. As a result, a complete change in the composition of the aCSF from a control solution to a test solution was delayed by approximately 15 to $20 \mathrm{sec}$. The figures presented in the Results section have not been corrected for this delay. Overall, this system permilted a rapid and homogeneous application, and equally rapid elimination of drugs. All drugs were dissolved and delivered in the perfusate (i.e., aCSF). Solutions used to depolarize NM neurons contained $60 \mathrm{mM} \mathrm{KCl}$. Calcium-free solutions were obtained by adding $5 \mu \mathrm{M}$ EGTA to nominally $\mathrm{Ca}^{2+}$-free aCSF. When testing for the effects of drugs under $\mathrm{Ca}^{2+}$-free conditions, slices were superfused with $\mathrm{Ca}^{2+}$ free aCSF for at least 2 min before and after agonist application.

Materials. Fura-2 was obtained from Molecular Probes, Inc. (Eugene, OR): Pharmaceuticals, with the exception of $\omega$-CgTX, VIP, and glutamate, were purchased from Research Biochemicals, Inc. (Natick, MA). $\omega$-CgTX was purchased from Peninsula Laboratories (Belmont, CA), while VIP was purchased from Calbiochem (La Jolla, CA). Glutamatc was acquired from Sigma. All other reagents were of analytical grade.

\section{Results}

Figure $1 A$ shows a photomicrograph of the avian nucleus magnocellularis (NM). The nucleus is composed of a single cell type, shown here stained with antibodies against microtubule-associated protein 2 which is used to reveal dendritic arborizations. These spherically shaped cells are roughly $30 \mu \mathrm{m}$ in diameter, and adendritic at this age (Boord, 1969; Parks and Rubel, 1978; Smith and Rubel, 1979; Jhaveri and Morest, 1982). A single neuron is usually innervated by two to three auditory nerve axons that terminate with endbulbs of Held. Figure $1 B$ shows a micrograph of NM neurons filled with Fura-2. Although there was some variation in the amount of indicator taken up by neurons, the cytosol was uniformly fluorescent, and the fluorescent emission was intense. In some neurons, the fluorescent intensity of the nucleus was noticeably greater than the fluorescent intensity of the cytoplasm.

The average basal intracellular calcium ion concentration of the neurons examined in this study was $78 \pm 25 \mathrm{nM}$ (SEM). A few neurons exhibited high basal $\left[\mathrm{Ca}^{2+}\right]_{i}$, some in the neighborhood of $200 \mathrm{nM}$, others exceeding $1000 \mathrm{~nm}$. These cells were presumably damaged by the dissection and were not evaluated. Of the 25 to 30 cells visible in the microscopic field, approxi- 

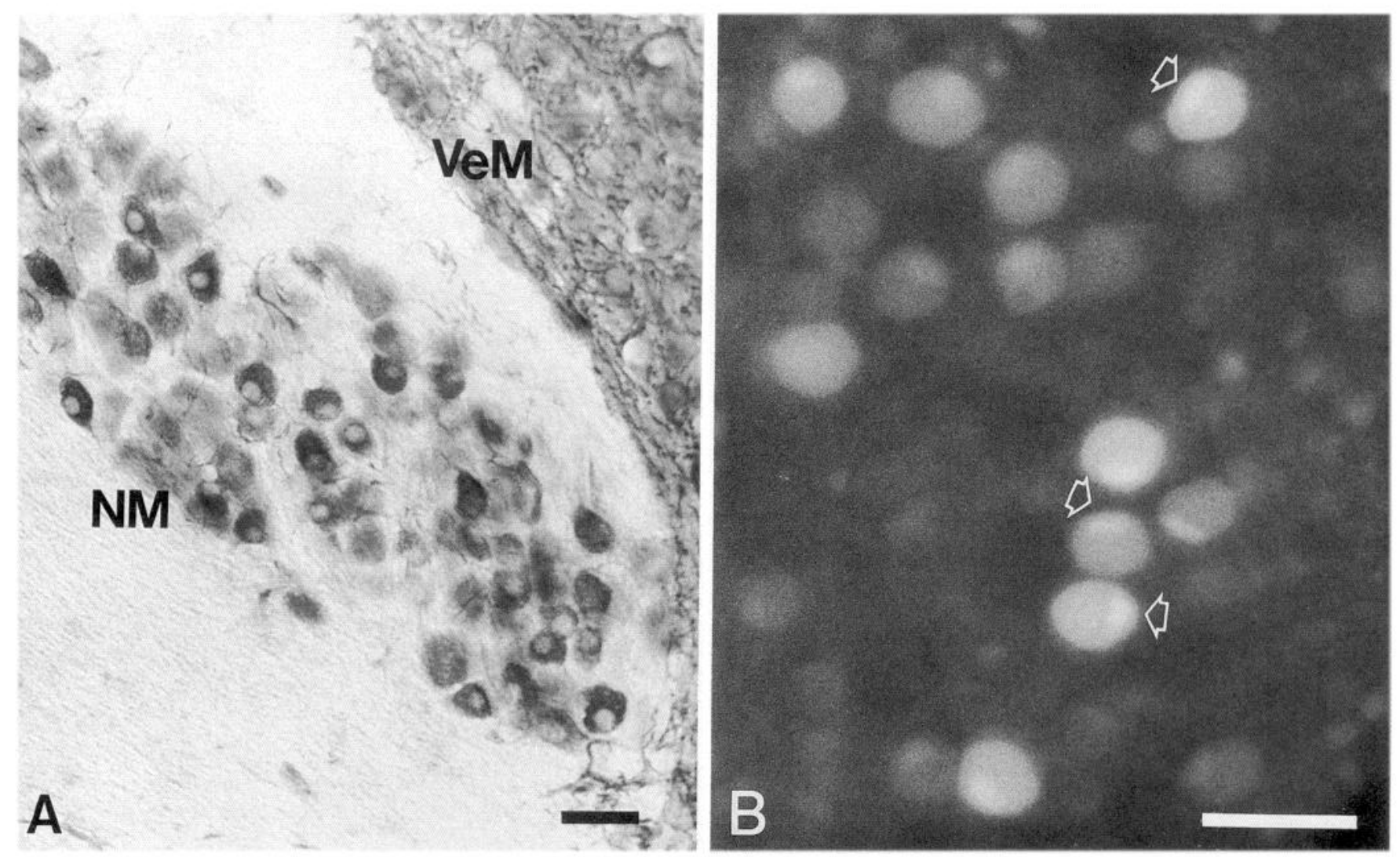

Figure 1. Nucleus magnocellularis (NM) neurons stained for microtubule-associated protein 2 (MAP-2) and Fura-2. A, As revealed by MAP-2 staining, NM is composed of round, adendritic neurons. B, This micrograph shows FURA-2-labeled neurons. In some neurons, the fluorescent intensity of the nucleus was significantly greater than that of the cytosol (arrows). VeM, medial vestibular nucleus; $N M$, nucleus magnocellularis. Scale bars, $40 \mu \mathrm{m}$.

mately $10 \%$ were excluded from analyses because of elevated $\left[\mathrm{Ca}^{2+}\right]_{i}$. Changes in $\left[\mathrm{Ca}^{2+}\right]_{i}$ are reported as the mean \pm SEM. The total number of neurons examined (attended parenthetically by the number of slices used) is reported below.

\section{NM neurons possess at least two different VOCCS}

The graph in Figure $2 A$ plots, over time, the change in $\left[\mathrm{Ca}^{2+}\right]_{i}$ $\left(\mathrm{Ca}^{2+}\right.$ response) that was seen in a single neuron depolarized by $60 \mathrm{mM} \mathrm{KCl}$. The onset of $\mathrm{KCl}$ stimulation is indicated by the left-most dotted line, while the termination of $\mathrm{KCl}$ stimulation is shown by the second vertical line. Superfusion of $60 \mathrm{mM} \mathrm{KCl}$ caused an increase in $\left[\mathrm{Ca}^{2+}\right]_{i}$. The kinetic and temporal properties of the $\mathrm{Ca}^{2+}$ response in 64 depolarized neurons $(n=7)$ examined were highly stereotypic: a slow, but brief increase in $\left[\mathrm{Ca}^{2+}\right]_{i}$ was initially seen followed by a sudden, rapid, increase to $977 \pm 193 \mathrm{~nm}$ (a $\mathrm{Ca}^{2+}$ transient). An equally rapid decay to near basal levels occurred after the $\left[\mathrm{K}^{+}\right]_{o}$ was returned to normal levels. The complete return to basal $\left[\mathrm{Ca}^{2+}\right]_{i}$ was protracted, however; $91 \%$ of the neurons reestablished basal $\left[\mathrm{Ca}^{2+}\right]_{i} 5$ to $7 \mathrm{~min}$ after the depolarization. Figure $2 B$ shows the $\mathrm{Ca}^{2+}$ responses of eight neurons simultaneously imaged. The $\mathrm{Ca}^{2+}$ response caused by elevating $[\mathrm{K}+]_{o}$ could be evoked repeatedly, and the magnitude of the response and its temporal properties did not vary significantly between depolarizations. In the experiment illustrated in Figure $2 B$, these neurons were depolarized six times, each time by a $20 \mathrm{sec}$-long superfusion of $60 \mathrm{~mm} \mathrm{KCl}$. These results show that the simple influx of $\mathrm{Ca}^{2+}$ (or the mere exposure to $\mathrm{KCl}$ ) does not affect the magnitude of subsequent $\mathrm{Ca}^{2+}$ re- sponses produced by $\mathrm{KCl}$. $\mathrm{Ca}^{2+}$ transients were not observed when NM neurons were depolarized in $\mathrm{Ca}^{2+}$-free aCSF.

The influx of $\mathrm{Ca}^{2+}$ in NM neurons can be carried by a single or a set of voltage-operated $\mathrm{Ca}^{2+}$ channels (VOCCs); three different channels have been identified: L-, N-, and T-type (Nowycky et al., 1985; Fox et al., 1987a,b; see Bean, 1989, for review). The $\mathrm{L}$ - and $\mathrm{N}$-type channels are activated by large changes in membrane voltage, while the T-type channels are activated by smaller changes in membrane voltage. Since it is most likely that the $\mathrm{Ca}^{2+}$ transients produced by $60 \mathrm{~mm} \mathrm{KCl}$ are carried by high voltage activated (HVA) L- or N-type channels, rather than low voltage activated (LVA), or T-type channels, the effects of HVA agonists and antagonists were tested on $\mathrm{KCl}$ stimulated $\mathrm{Ca}^{2+}$ influx. Specifically, dihydropyridine (DHP) agonists and antagonists were used to determine if NM neurons express L-channels (see Carbone and Swandulla, 1989; Sher et al., 1991, for review of DHP actions); $\omega$-CgTX was used to test for N-channels (see Fox et al., 1987a).

NM neurons express L-type channels. The effect of BAY K 8644 was examined on 24 neurons ( $n=3$ slices) depolarized by $30 \mathrm{mM} \mathrm{KCl}$. As seen in Figure $3 A$, the change in $\left[\mathrm{Ca}^{2+}\right]_{i}$ caused by elevating the $[\mathrm{K}+]_{o}$ to $30 \mathrm{~mm}$ was negligible (inset, Fig. 3A). A larger influx of $\mathrm{Ca}^{2+}$ was seen when $30 \mathrm{~mm} \mathrm{KCl}$ and $10 \mu \mathrm{M}$ BAY $\mathrm{K} 8644$ were coapplied. In the presence of 30 $\mathrm{mM} \mathrm{KCl}$ alone, $\left[\mathrm{Ca}^{2+}\right]_{i}$ increased to $87 \pm 22 \mathrm{nM}$. The $\left[\mathrm{Ca}^{2+}\right]_{i}$ increased to $161 \pm 33 \mathrm{nM}$ when $\mathrm{KCl}$ and $\mathrm{BAY} \mathrm{K} 8644$ were coapplied. 
A
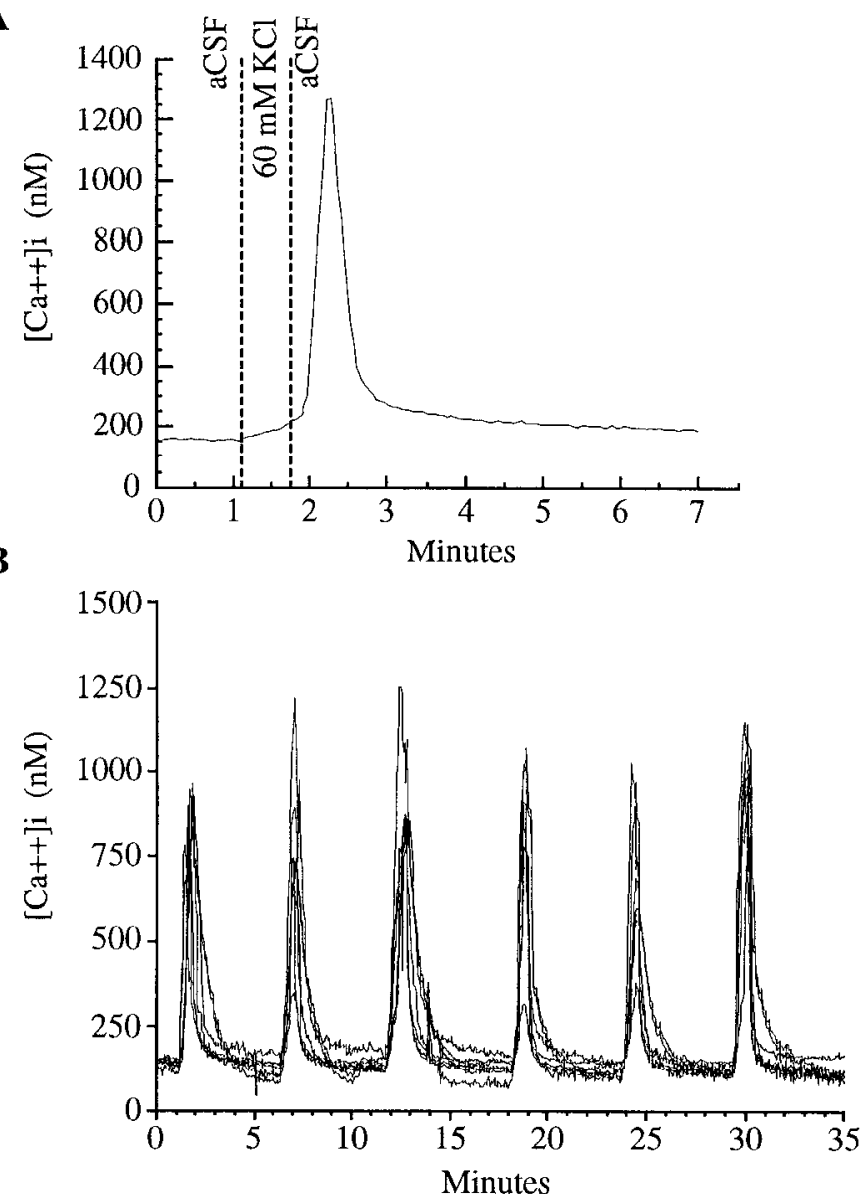

Figure 2. Voltage-dependent $\mathrm{Ca}^{2+}$ response of NM neurons. $A$, When depolarized by $60 \mathrm{mM} \mathrm{KCl}$, neurons responded with a large increase in $\left[\mathrm{Ca}^{2+}\right]_{i}$. A calcium transient for a single NM neuron is illustrated here. $B$, Calcium responses for eight neurons are plotted, depolarized by six sequential applications of $\mathrm{KCl}$. Large $\mathrm{Ca}^{2+}$ transients were observed each time $60 \mathrm{~mm} \mathrm{KCl}$ was superfused.

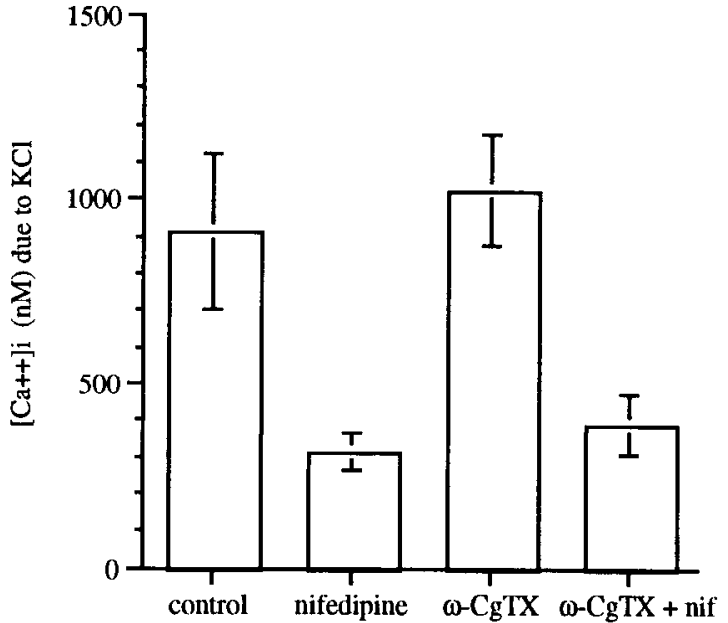

Figure 4. NM neurons do not possess $\omega$-CgTX-conotoxin sensitive $\mathrm{Ca}^{2+}$ channels. $A$, These histograms show the $\left[\mathrm{Ca}^{2+}\right]_{i}$ seen in NM neurons depolarized by $60 \mathrm{~mm} \mathrm{KCl}$ under four different conditions: control (normal aCSF), in the presence of $1 \mu \mathrm{M}$ nifedipine, following a $15 \mathrm{~min}$ preincubation in $2.5 \mu \mathrm{M} \omega-\mathrm{CgTX}$ conotoxin, and in the presence of 1 $\mu \mathrm{M}$ nifedipine following $\omega-\mathrm{CgTX}$ incubation. A Student's $t$ test revealed that nifedipine significantly attenuated the increase in $\left[\mathrm{Ca}^{2+}\right]_{i}$ due to $\mathrm{KCl}(p<0.001)$. The change in $\left[\mathrm{Ca}^{2+}\right]$ seen in $\mathrm{KCl}$-depolarized neurons preincubated in $\omega-\mathrm{CgTX}$ did not differ statistically from controls.

Whereas the DHP agonist BAY K 8644 augmented $\mathrm{Ca}^{2+}$ influx, the DHP antagonist nifedipine attenuated $\mathrm{Ca}^{2+}$ influx. A total of $41(n=5)$ neurons were examined. The coapplication of $500 \mathrm{~nm}$ nifedipine and $60 \mathrm{~mm} \mathrm{KCl}$ did not completely block $\mathrm{Ca}^{2+}$ influx (Fig. 3B): small elevations in $\left[\mathrm{Ca}^{2+}\right]_{i}$ were seen, but large $\mathrm{Ca}^{2+}$ transients were not. In the absence of nifedipine, the mean $\left[\mathrm{Ca}^{2+}\right]_{i}$ increased to $912 \pm 213 \mathrm{nM}$; in the presence of nifedipine, the mean $\left[\mathrm{Ca}^{2+}\right]_{i}$ increased to $310 \pm 53 \mathrm{~nm}$. The $\mathrm{Ca}^{2+}$ responses of NM neurons preincubated in $2.5 \mu \mathrm{M} \omega-\mathrm{CgTX}$ (see Fig. 4) and depolarized in the absence and presence of 500 nM nifedipine did not differ significantly from the responses of
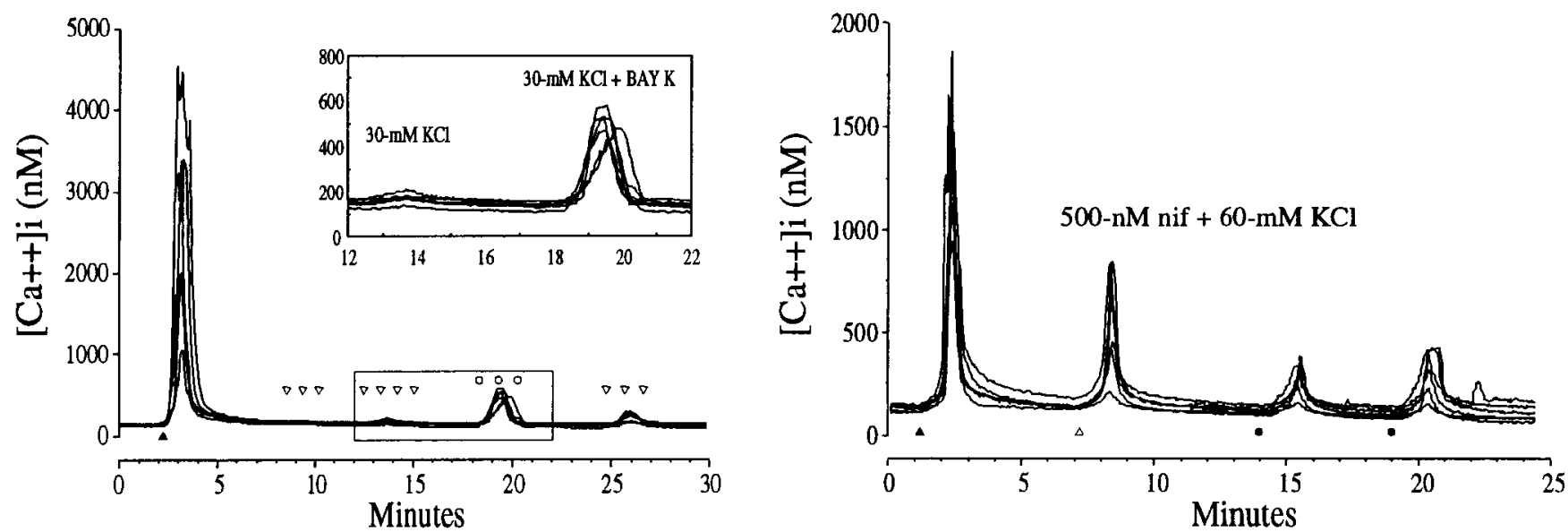

Figure 3. Dihydropyridines (DHP) alter the $\mathrm{Ca}^{2+}$ responses of NM neurons depolarized by elevated $[\mathrm{K}+]_{\circ} . A$, Calcium responses of neurons depolarized by $60 \mathrm{mM} \mathrm{KCl}$ for $20 \mathrm{sec}$, by $30 \mathrm{mM} \mathrm{KCl}$ for $2 \mathrm{~min}$, and by $30 \mathrm{mM} \mathrm{KCl}+10 \mu \mathrm{M} \mathrm{BAY} \mathrm{K} 8644$ for $2 \mathrm{~min}$, are shown for six neurons. $\mathrm{KCl}(60 \mathrm{mM})$ (black triangle) caused the $\left[\mathrm{Ca}^{2+}\right]_{i}$ to significantly rise. A smaller change in $\left[\mathrm{Ca}^{2+}\right]_{i}$ was produced by $30 \mathrm{~mm} \mathrm{KCl}$ (white triangles, and see inset). A larger change in $\left[\mathrm{Ca}^{2+}\right]$, was seen when $30 \mathrm{mM} \mathrm{KCl}$ and the DHP agonist BAY K 8644 (white circles) were coapplied. B, Calcium responses of five neurons depolarized by $60 \mathrm{mM} \mathrm{KCl}$ before (black triangle), during (white triangle), and after (black circles) neurons were exposed to the DHP "antagonist" nifedipine $(500 \mathrm{nM})$. Following nifedipine exposure, large $\mathrm{Ca}^{2+}$ transients were no longer observed. 

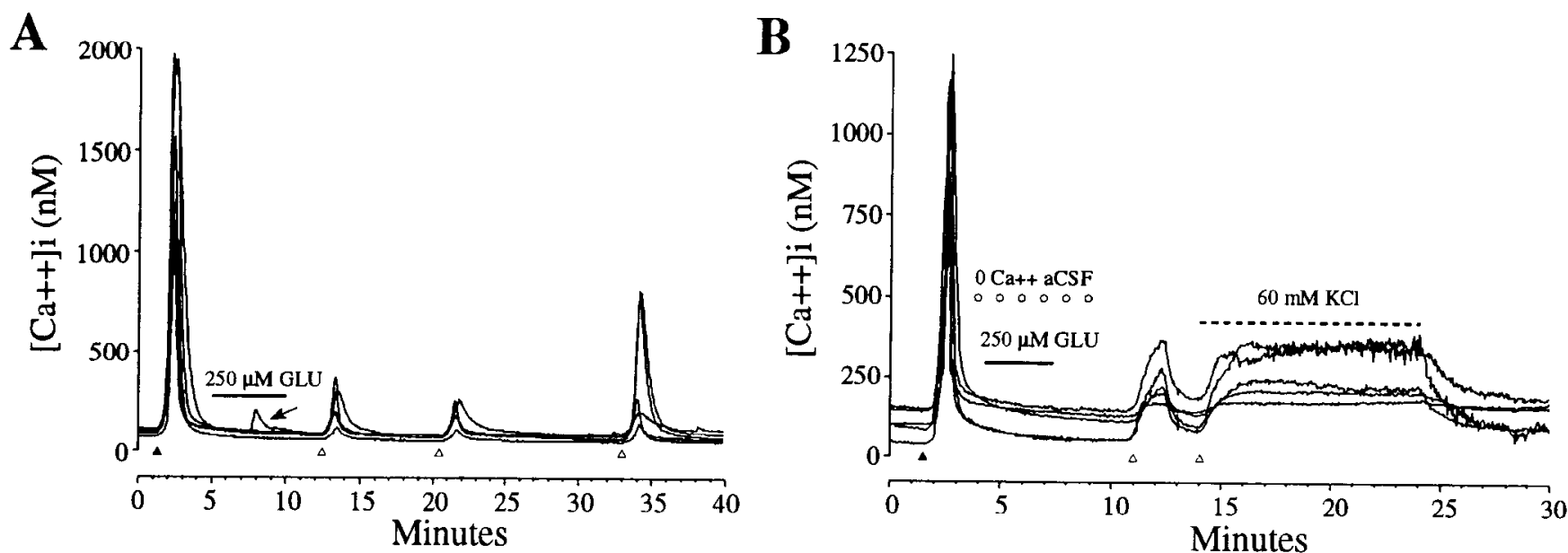

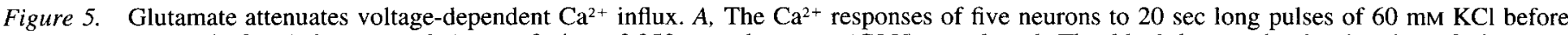

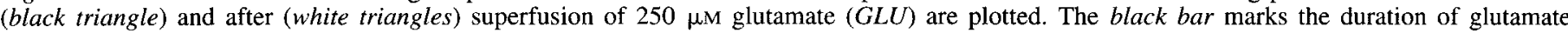

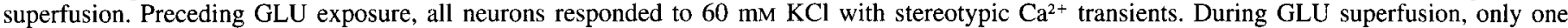

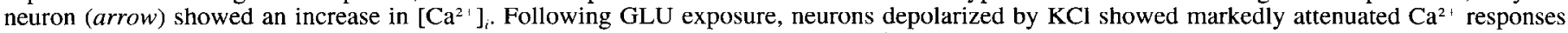

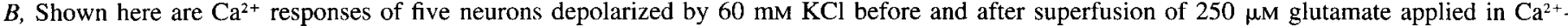

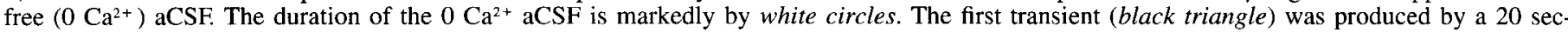

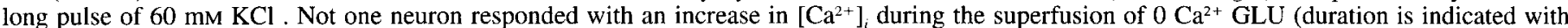

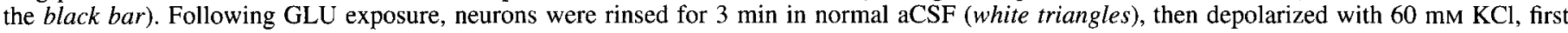
for $2 \mathrm{~min}$, then for $10 \mathrm{~min}$ (indicated by the dashed bar).

neurons that were not exposed to $\omega-\mathrm{CgTX}\left(\left[\mathrm{Ca}^{2+}\right]_{i}\right.$ for $\omega$-CgTX calone $=1023 \pm 151 \mathrm{nM}$ vs. $\omega-\mathrm{CgTX}+$ nifedipine $=388 \pm$ $84 \mathrm{nM})$.

In summary, NM neurons responded in a predictable fashion when they were depolarized hy elevated $[\mathrm{K}+]_{v}$ : a rapidly developing large $\mathrm{Ca}^{2+}$ transient was produced that could be blocked with the L-channel antagonist, nifedipine. $\mathrm{Ca}^{2+}$ influx in depolarized NM neurons was not changed by $\omega-\mathrm{CgTX}$, indicating that NM neurons at this age do not possess $\mathrm{N}$-type calcium channels.

\section{Glutamate attenuates voltage-dependent $\mathrm{Ca}^{2+}$ flow}

Concentrations of glutamate $(100 \mu \mathrm{M}$ to $500 \mu \mathrm{M})$ that are known to change the membrane potential of NM neurons (Raman and Trussell, 1992; Trussell et al., 1993) do not reliably increase $\left[\mathrm{Ca}^{2+}\right]_{i}$ (Zirpel et al., 1994b). Reliable changes in $\left[\mathrm{Ca}^{2+}\right]_{i}$ can be produced by $5 \mathrm{~mm}$ glutamate. While submillimolar concentrations of glutamate were ineffective in stimulating $\mathrm{Ca}^{2+}$ influx, they were effective in altering the flow of $\mathrm{Ca}^{21}$ through VOCCs. Several tests were conducted to show that an attenuation of $\mathrm{Ca}^{2+}$ influx by glutamate was not mediated by ionotropic glutamate receptors. $\mathrm{Ca}^{2+}$ influx was suppressed by quisqualate and $t$-ACPD, agonists of mGluRs. Finally, the attenuation of $\mathrm{Ca}^{2+}$ influx was not blocked by CNQX, an antagonist of non-NMDAtype receptor-operated channels (ROCs), or by L-AP3 or L-AP4, which block mGluR actions in other systems (Schoepp and Johnson, 1989; Forsythe and Clements, 1990; Schoepp et al., 1990; Baskys and Malenka, 1991; Tanabe et al., 1991; Trombley and Westbrook, 1992).

Figure 5 plots the $\mathrm{Ca}^{2+}$ responses of NM neurons depolarized by $60 \mathrm{mM} \mathrm{KCl}$ before and after glutamate superfusion. These responses are representative of the 57 neurons $(n=7)$ that were tested after superfusion of $200 \mu \mathrm{M}$ to $500 \mu \mathrm{M}$ glutamate. Following glutamate exposure, an attenuation in $\mathrm{Ca}^{2+}$ influx due to $\mathrm{KCl}$ was seerl: $72 \%$ of the depolarized neurons responded with small increases in $\left[\mathrm{Ca}^{2+}\right]_{i}$, averaging $102 \pm 32 \mathrm{nM}$. The re- mainder showed a larger influx of $\mathrm{Ca}^{2+}$, averaging $310 \pm 73$ nM. The $\mathrm{Ca}^{2+}$ response seen in the other set of neurons developed slowly to a plateau then decreased gradually to basal levels once $\mathrm{KCl}$ stimulation was removed. $\mathrm{Ca}^{2+}$ transients were never produced by depolarizations administered after glutamate superfusion. A long exposure to glutamate, 3 to $5 \mathrm{~min}$ in duration, was required to attenuate the influx of $\mathrm{Ca}^{2+}$. As illustrated in Figure $5 \mathrm{~A}$, the effect was also long lasting. It was also reversible (not illustrated), returning to prestimulus levels 40 to $50 \mathrm{~min}$ after glutamatergic stimulation. Figure $5 B$ shows that glutamatergic actions were not dependent upon extracellular $\mathrm{Ca}^{2+}$, indicating that calcium/calmodulin-dependent protein kinases, which have been shown to play a role in mGluR-mediated inhibition of $\mathrm{Ca}^{2+}$ influx through L-channels (Lester and Jahr, 1990; Chernevskaya et al., 1991; Nistri and Cherubini, 1991; Zeilhofer et al., 1993), do not play a role in this particular system.

Lastly, Figure $6 A$ summarizes the effects that different VOCC antagonists had on the $\mathrm{KCl}$-induced $\mathrm{Ca}^{2+}$ response following glutamate exposure. A total of 36 neurons $(n=3)$ were examined. The glutamatergically attenuated $\mathrm{Ca}^{2+}$ response was not reduced further by nifedipine: following glutamate exposure, 60 mM KCl increased $\left[\mathrm{Ca}^{2+}\right]_{i}$ to $288 \pm 88 \mathrm{nM}$; the $\left[\mathrm{Ca}^{2+}\right]_{i}$ rose to $257 \pm 91 \mathrm{~nm}$ in glutamatergically treated neurons that were simultaneously exposed to $60 \mathrm{mM} \mathrm{KCl}$ and $1 \mu \mathrm{M}$ nifedipine. The difference was not statistically significant. Attenuated $\mathrm{Ca}^{21}$ responses were reduced further by pimozide (see Fig. 6B), a diphenylbutylpiperidine that preferentially (albeit nonspecifically) blocks low voltage-activated calcium channels (Enyeart et al., 1990; Enyeart et al., 1993): $25 \mu \mathrm{M}$ pimozide further reduced the glutamatergically attenuated $\mathrm{Ca}^{2+}$ response from roughly 250 to $93 \pm 25 \mathrm{nM}$. This concentration was not statistically different from basal levels. These results indicate that glutamate modulates L-type channels.

$Q A$ and t-ACPD also block VOCCs. Seven slices were exposed to glutamate agonists KA $(n=2)$, AMPA $(n=2)$, and 

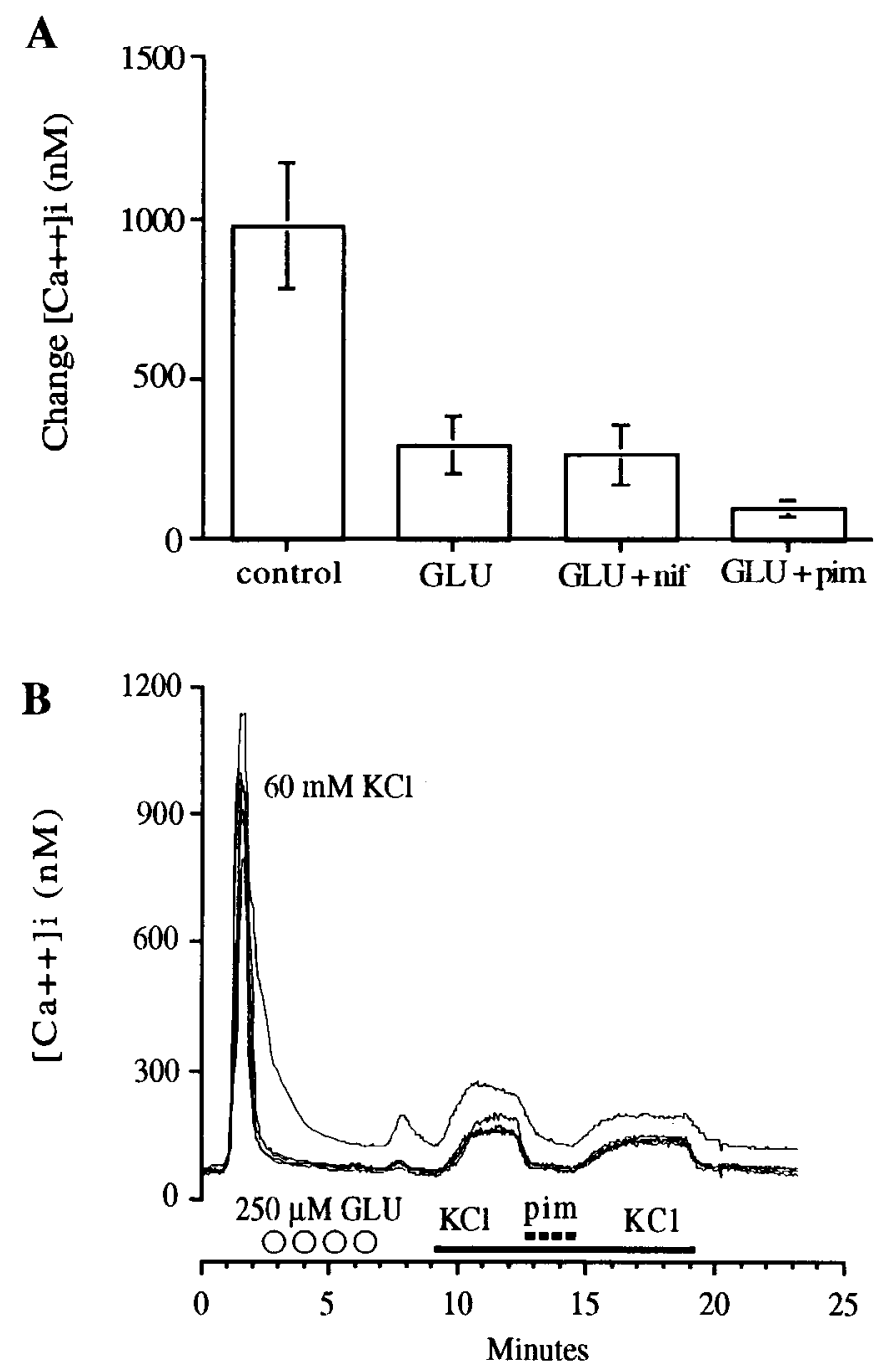

Figure 6. Glutamate modulates L-type channels. A, This histogram summarizes the mean elevation in $\left[\mathrm{Ca}^{2+}\right]_{i}( \pm \mathrm{SEM})$ induced by $\mathrm{KCl}$ under four separate conditions: control, $\mathrm{KCl}$ before glutamate superfusion; $G L U, \mathrm{KCl}$ after a 5 min glutamate superfusion; $G L U+n i f$, coapplication of $\mathrm{KCl}$ and nifedipine after glutamate superfusion; $G L U$ + pim, coapplication of $\mathrm{KCl}$ and pimozide after glutamate superfusion. $B$, Shown are $\mathrm{Ca}^{2+}$ responses of five neurons to $60 \mathrm{mM} \mathrm{KCl}$ before and after superfusion of $250 \mu \mathrm{M}$ glutamate (indicated by the white circles). The first $\mathrm{Ca}^{2+}$ transient was produced by a 20 sec-long exposure to $\mathrm{KCl}$, the second transient was produced by a 1 min long exposure to $\mathrm{KCl}$. The black bar indicates the period of time $60 \mathrm{mM} \mathrm{KCl}$ was continuously superfused. When $25 \mu \mathrm{M}$ pimozide was coapplied (indicated by dashed line) during the $\mathrm{KCl}$ stimulus, the $\left[\mathrm{Ca}^{2+}\right]_{i}$ was reduced to near hasal levels. The $\left[\mathrm{Ca}^{2+}\right]_{i}$ elevated after the pimozide was removed.

QA $(n=3)$, then depolarized with $\mathrm{KCl}$. These results are summarized in Figure 7. Slices were not exposed to NMDA because it is not clear whether NM neurons express functional NMDAtype receptors beyond embryonic day 14 (Nemeth et al., 1983; Raman and Trussell, 1992; Zhou and Parks, 1992). Previous studies have shown that, unlike glutamate, brief exposure to 25 $\mu \mathrm{M}$ KA, $25 \mu \mathrm{M}$ AMPA, and $25 \mu \mathrm{M}$ QA causes an increase in $\left[\mathrm{Ca}^{2+}\right]_{i}$ (Zirpel et al., 1994b). These concentrations of KA or AMPA did not alter voltage-dependent $\mathrm{Ca}^{2+}$ influx. Quisqualate, on the other hand, produced a long-lasting and reversible reduction in $\mathrm{Ca}^{2+}$ influx through VOCCs (see Fig. 7). The actions of QA were consistently and reliably produced when QA was coap-

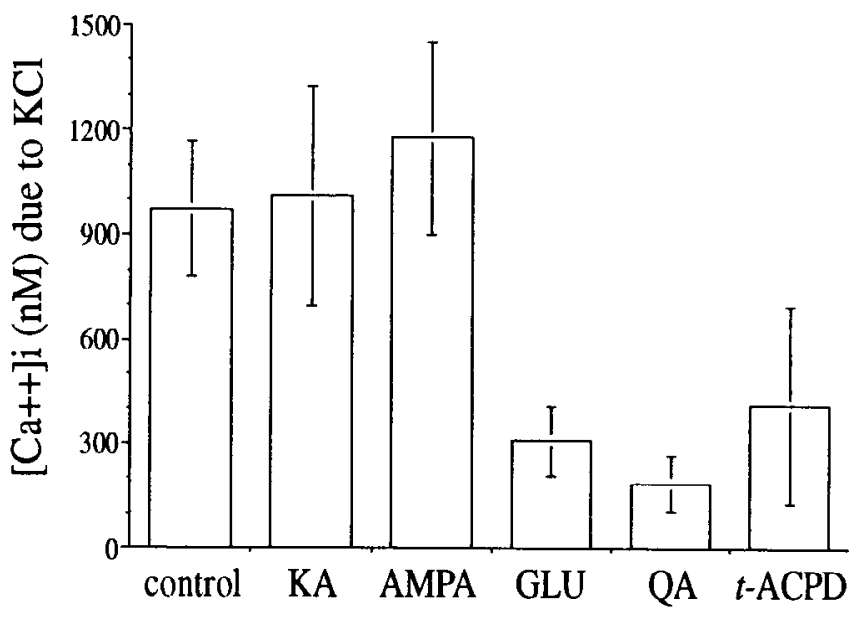

Figure 7. Stimulation of a $\mathrm{mGluR}$ is required to attenuate voltagedependent $\mathrm{Ca}^{2+}$ influx. Summarized by this histogram are the mean $\mathrm{C} \pm$ SEM) $\left[\mathrm{Ca}^{2+}\right]$, seen in neurons depolarized by $60 \mathrm{mM} \mathrm{KCl}$ alone (control), or by $\mathrm{KCl}$ immediately after a 3 to $5 \mathrm{~min}$ exposure to $25 \mu \mathrm{M} \mathrm{KA}$ or AMPA, to $250 \mu \mathrm{M}$ glutamate $(G L U)$, to $25 \mu \mathrm{M}$ quisqualate $(Q A)$, or to $100 \mu \mathrm{M}$-ACPD. The magnitude of voltage dependent $\mathrm{Ca}^{2+}$ influx was reduced in NM neurons superfused with GLU, QA, or $t$-ACPD. A Student's $t$ test revealed that the difference in $\mathrm{Ca}^{2+}$ influx following GLU or QA exposure was statistically significant $(p<0.001)$ compared to controls; the voltage-dependent influx of $\mathrm{Ca}^{2+}$ observed following $t$-ACPD superfusion, while attenuated compared to controls, did not differ statistically $(p<0.08)$.

plied with $50 \mu \mathrm{M}$ CNQX to block QA-stimulated ionotropic receptor channels.

Six slices were exposed to $100 \mu \mathrm{M} t$-ACPD then depolarized. Like glutamate, $t$-ACPD $(50 \mu \mathrm{M}$ to $200 \mu \mathrm{M})$ did not evoke a $\mathrm{Ca}^{2+}$ response in NM neurons (see Zirpel et al., 1994b, for details). Unlike glutamate, $t$-ACPD at these concentrations reduced the $\left[\mathrm{Ca}^{2+}\right]_{i}$ below basal levels to $42 \pm 27 \mathrm{nM}$. This reduction in basal $\left[\mathrm{Ca}^{2+}\right]_{i}$ was not statistically different from normal. The effects of $100 \mu \mathrm{M} t$-ACPD were examined on $27 \mathrm{NM}$ neurons $(n=5)$. In $66 \%$ of these neurons $t$-ACPD significantly decreased the $\mathrm{KCl}$ evoked influx of $\mathrm{Ca}^{2+}$ (see Fig. 7). The remainder responded to the $\mathrm{KCl}$ stimulus with large transients. Higher concentrations of $t$-ACPD were less effective at reducing the $\mathrm{KCl}$-evoked $\mathrm{Ca}^{2+}$ transients.

Channel inhibition is not blocked by $i G l u R$ antagonists. Concentrations of CNQX that block KA- or AMPA-croked $\mathrm{Ca}^{2+}$ responses (Zirpel et al., 1994b) did not reverse glutamatergic inhibition of $\mathrm{Ca}^{2+}$ influx. A total of five slices were incubated in $25 \mu \mathrm{M}$ CNQX $+250 \mu \mathrm{M}$ glutamate, then depolarized by $\mathrm{KCl}$. Not one of the 39 neurons examined responded with a $\mathrm{Ca}^{2+}$ transient. These results are summarized in Figure $8 \mathrm{~A}$.

The effects of L-AP3 (Schoepp and Johnson, 1989; Schoepp et al., 1990), L-AP4, and SOP (Nicolletti et al., 1986; Winder et al., 1993), which block the actions of different mGluRs, are summarized in Figure $8 B$. The actions of L-AP3 were examined on a total of 25 neurons $(n=5)$. Not one of these neurons showed a $\mathrm{Ca}^{2+}$ transient in response to $60 \mathrm{mM} \mathrm{KCl}$ subsequent to coapplication of $200 \mu \mathrm{M}$ glutamate and $1 \mathrm{mM}$ L-AP3. The actions of L-AP4 were examined in 33 neurons $(n=6)$. Like L-AP3, L-AP4 did not alter the inhibitory actions of glutamate on VOCCs. Finally, the effects of SOP were examined on 27 neurons $(n=7)$. Each neuron responded with a $\mathrm{Ca}^{2+}$ transient each time it was stimulated by $\mathrm{KCl}$. 
$\mathbf{A}$

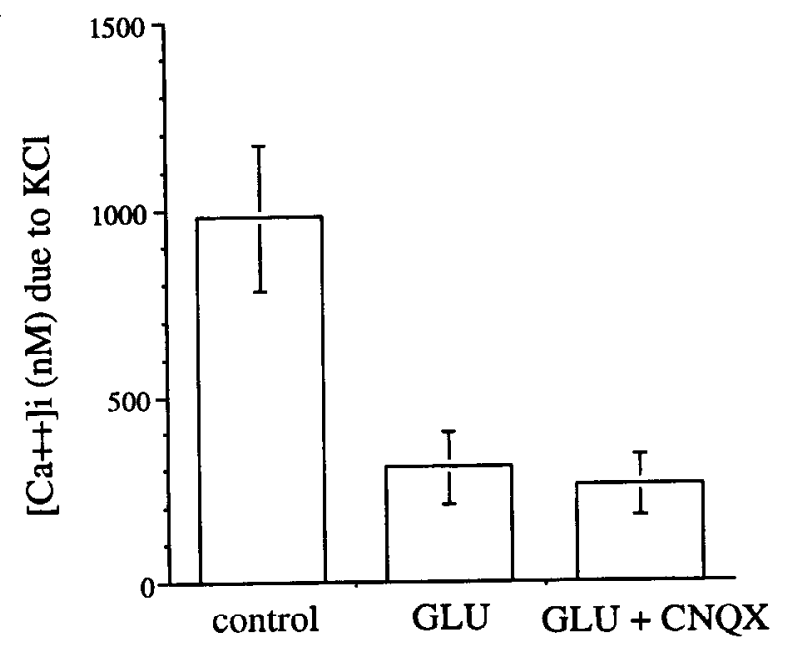

B

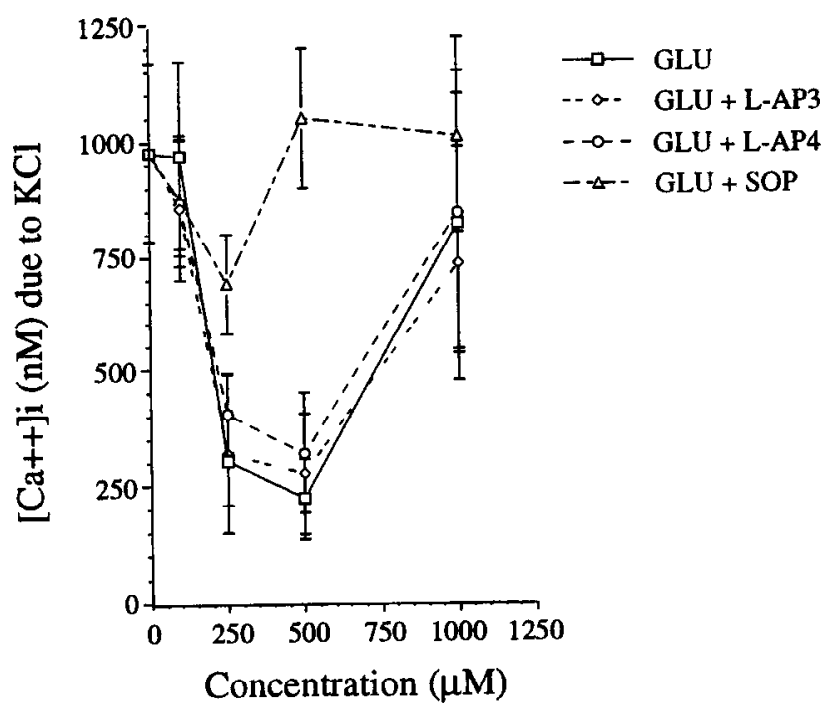

Figure 8. Glutamatergic actions on voltage-dependent $\mathrm{Ca}^{2+}$ influx are antagonized by phosphoserine. $A$, The magnitude of $\mathrm{Ca}^{2+}$ influx caused by $60 \mathrm{mM} \mathrm{KCl}$ following a $3 \mathrm{~min}$ exposure to $250 \mu \mathrm{M}$ glutamate $(G L U)$ or to $25 \mu \mathrm{M}$ CNQX $+250 \mu \mathrm{M}$ GLU is compared to changes in $\left[\mathrm{Ca}^{2+}\right]$ produced by $\mathrm{KCl}$ in untreated slices (control). B, The magnitude of $\mathrm{Ca}^{2+}$ influx caused by $60 \mathrm{mM} \mathrm{KCl}$ following a $3 \mathrm{~min}$ exposure to 250 $\mu \mathrm{M}$ glutamate $(G L U)$ alone, or glutamate $+\mathrm{L}-\mathrm{AP} 3$, glutamate + L-AP4, or glutamate + SOP, are shown here, presented as dose-response curves. Glutamatergic inhibition of voltage-dependent $\mathrm{Ca}^{2+}$ influx is most effective at concentrations less than $500 \mu \mathrm{M}$, and is inhibited by serine- $O$-phosphate, not L-AP3 or L-AP4.

\section{Voltage-dependent $\mathrm{Ca}^{2+}$ influx is attenuated by cAMP}

mGluR activation modulates a variety of intracellular messengers. The most widely recognized mGluR effect is the stimulation of IP3 formation via activation of a phospholipase C (PLC) signal transduction cascade (Schoepp and Conn, 1993, for review). Other mGluRs activate phospholipase D (Boss and Conn, 1992; Holler et al., 1993), inhibit forskolin-stimulated adenylate cyclase activity (Schoepp et al., 1992; Tanabe et al., 1992; Schoepp and Johnson, 1993) or stimulate cAMP accumulation (Goh and Ballyk, 1993; Winder and Conn, 1993; Winder et al., 1993). The experiments described below suggest that an accu-

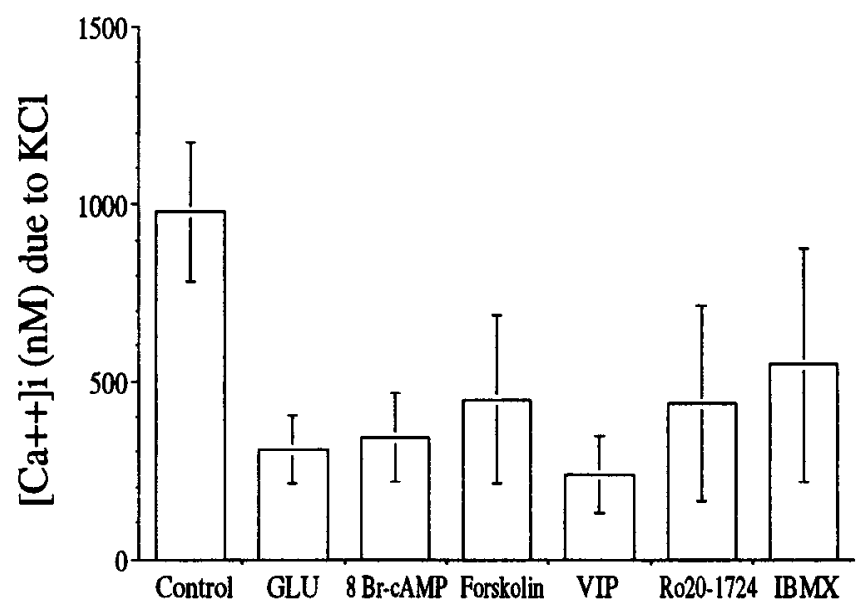

Figure 9. Accumulators of cAMP attenuate voltage-dependent $\mathrm{Ca}^{2+}$ influx. This histogram summarizes the mean changes $( \pm$ SEM) in $\left[\mathrm{Ca}^{2+}\right]_{i}$ seen in neurons depolarized by $60 \mathrm{mM} \mathrm{KCl}$ alone (control), or by $\mathrm{KCl}$ immediately after a prolonged exposure to $250 \mu \mathrm{M}$ glutamate $(G L U)$, to $1 \mathrm{mM} 8 \mathrm{Br}$-cAMP, to $50 \mu \mathrm{M}$ forskolin, to $1 \mu \mathrm{M}$ VIP, to 250 $\mu \mathrm{M}$ Ro $20-1724$, or $100 \mu \mathrm{M}$ IBMX. The magnitude of voltage-dependent $\mathrm{Ca}^{2+}$ influx that was reduced in NM neurons by $8 \mathrm{Br}$-cAMP and VIP, was similar to that produced by GLU, and were statistically different from control levels $(p<0.001)$. While forskolin attenuated $\mathrm{Ca}^{2+}$ influx, the difference was not statistically significant $(p<0.07)$. The phosphodiesterase inhibitors also attenuated $\mathrm{Ca}^{2+}$ influx, but not as effectively as GLU, or the other cAMP-accumulators, and their overall effect on $\mathrm{Ca}^{2+}$ influx compared to controls was not statistically significant.

mulation of CAMP may be involved in glutamatergic modulation of VOCC.

That an increase in $\left[\mathrm{Ca}^{2+}\right]_{i}$ was not required to attenuate voltage-dependent $\mathrm{Ca}^{2+}$ influx (see Fig. 5B) indicated that IP3, a product of the PLC signal transduction cascade, was not involved in glutamatergic modulation of $\mathrm{Ca}^{2+}$ channels. To determine whether diacylglycerol (DAG) and its effector, protein kinase $\mathrm{C}(\mathrm{PKC})$, played any role in VOCC inhibition, 26 neurons $(n=4)$ were incubated in the PKC-activating phorbol ester PMA (1 $\mu \mathrm{M}$ ) for 12 to $15 \mathrm{~min}$ then stimulated with $60 \mathrm{mM} \mathrm{KCl}$. Every one of the neurons exposed to the phorbol ester responded to $\mathrm{KCl}$ with a large $\mathrm{Ca}^{2+}$ transient. These results indicate that the products of PLC signal transduction system were not involved in glutamatergic inhibition of voltage-dependent $\mathrm{Ca}^{2+}$ influx. Considering these findings, voltage-dependent changes in $\left[\mathrm{Ca}^{2+}\right]_{i}$ were reexamined in NM neurons with pharmacologically elevated $[\mathrm{cAMP}]_{i}$. This was accomplished by incubating slices for 10 to $17 \mathrm{~min}$ in the adenylate cyclase activators forskolin $(50 \mu \mathrm{M})$, or VIP $(1 \mu \mathrm{M})$, or in the membrane permeable analog of cyclic AMP, 8-Br-cAMP (1 mM). To determine whether nominal concentrations of cAMP could attenuate $\mathrm{KCl}$-stimulated $\mathrm{Ca}^{2+}$ influx, a few slices were incubated for $20 \mathrm{~min}$ in phosphodiesterase inhibitors, either Ro 20-1724 (250 $\mu \mathrm{M})$ or IBMX (100 $\mu \mathrm{M})$. Following a brief rinse in aCSF, neurons were depolarized with $60 \mathrm{mM} \mathrm{KCl}$, and the ensuing change in $\left[\mathrm{Ca}^{2+}\right]_{i}$ was observed. The results of these tests are summarized in Figure 9.

Every neuron incubated in forskolin $(53 ; n=7)$, VIP $(24 ; n$ $=3)$, and 8-Br-cAMP $(30 ; n=3)$ showed basal $\left[\mathrm{Ca}^{2+}\right]_{i}$ that was lower (but not statistically different) than normal (treated $=$ $55 \pm 21 \mathrm{nM}$ vs. control $=78 \pm 25 \mathrm{nM}$ ). Neurons incubated in Ro 20-1724 (18; $n=3)$ and IBMX $(21 ; n=4)$ showed normal basal $\left[\mathrm{Ca}^{2+}\right]_{i}(82 \pm 21 \mathrm{nM})$. The mean change in $\left[\mathrm{Ca}^{2+}\right]_{i}$ in $\mathrm{KCl}-$ stimulated neurons incubated in each of the cAMP accumulators 
was smaller than that seen in untreated neurons; a nonparametric analysis of variance revealed that the difference between normal and accumulator-treated neurons was statistically different. An a priori comparison matching the effects of the PDE inhibitors against the remaining cAMP accumulators showed that the significant $F$ value produced by the ANOVA was not due to the effects of the PDE inhibitors. Thus, a significant increase in $[\mathrm{cAMP}]_{i}$ (which could not be completely produced by reducing PDE activity) was required to attenuate voltage-dependent changes in $\left[\mathrm{Ca}^{2+}\right]_{i}$. Post hoc comparisons testing the individual effects of forskolin, VIP, and 8-Br-cAMP revealed that the attenuation of $\mathrm{Ca}^{2+}$ influx caused by forskolin was not statistically different from normal, while the changes due to VIP or 8-BrcAMP were. It is notable that $58 \%$ of the forskolin-treated neurons did not show a $\mathrm{Ca}^{2+}$ transient when depolarized; the remainder responded with a large transient that was eliminated following a brief $(1 \mathrm{~min}$ ) superfusion of $100 \mu \mathrm{M}$ glutamate + $10 \mu \mathrm{M}$ forskolin. The effect of glutamate and forskolin on this second set of NM neurons was synergistic, as neither $100 \mu \mathrm{M}$ glutamate by itself (see Fig. 8) or $10 \mu \mathrm{M}$ forskolin by itself, could block the KCl-stimulated changes in $\left[\mathrm{Ca}^{2+}\right]_{i}$.

\section{Discussion}

Glutamate stimulates two different receptor types (Sugiyama et al., 1989): ionotropic receptors, linked to ion channels, and metabotropic receptors, which activate signal transduction cascades. In this study, the ratiometric $\mathrm{Ca}^{2+}$ indicator dye Fura-2 was used to show that concentrations of glutamate that produce a depolarization in NM neurons (Raman and Trussell, 1992) attenuates $\mathrm{Ca}^{2+}$ influx through voltage-sensitive channels, via the activation of a mGluR. The main results show that (1) NM neurons possess high voltage-activated $\mathrm{Ca}^{2+}$ channels; (2) the inhibition of $\mathrm{Ca}^{2+}$ influx caused by nifedipine and glutamate are equivalent; (3) glutamatergic attenuation of $\mathrm{Ca}^{2+}$ influx is long lasting, and duplicated by quisqualate and $t$-ACPD, but not KA or AMPA, and antagonized by serine- $O$-phosphate; (4) $\mathrm{Ca}^{2+}$ influx is also inhibited by increasing [cAMP $]_{i}$. It is important to add that a significant inhibition of $\mathrm{Ca}^{2+}$ influx cannot be achieved by inhibiting PDE activity. Thus, one possible explanation for the glutamatergic inhibition of voltage-dependent $\mathrm{Ca}^{2+}$ influx is that mGluR stimulation positively modulates adenylate cyclase activity, rather than negatively regulating the actions of PDEs.

This discussion addresses three topics. First, which mGluR produces the actions described in NM? The signal transduction pathways stimulated by seven cloned mGluRs, designated $\mathrm{m}$ GluR 1 through mGluR7, have been identified (Okamoto et al., 1994; and for review, see Schoepp and Conn, 1993). Phospholipase $\mathrm{C}$ is activated following stimulation of mGluR 1 and mGluR5 (Sugiyama et al., 1989; Masu et al., 1991; Abe et al., 1992; Aramori and Nakanishi, 1992). The remainder activate an inhibitory cAMP cascade (Nakajima et al., 1993; Tanabe et al., 1992, 1993; Okamoto et al., 1994). That accumulators of cAMP attenuate voltage-dependent $\mathrm{Ca}^{2+}$ influx indicates that the NM mGluR may modulate VOCCs by increasing the activity of the adenylate cyclase signal transduction system. Secondly, which $\mathrm{Ca}^{2+}$ channel is modulated? Studies examining the actions of mGluRs on VOCCs conclude that $\mathrm{N}$-channels are modulated. In NM neurons, mGluR stimulation appears to modulate L-channels. Finally, the functional significance of mGluR activation is discussed. Inhibition of VOCCs by mGluRs is believed to attenuate neurotransmission. In NM neurons, postsynaptic chan- nels appear to be modulated, and the second messengers involved in this modulation may be a critical link in the pathway for transneuronal degeneration due to activity deprivation.

mGluR stimulation inhibits calcium channels in NM neurons

Of the seven different mGluRs that have been cloned, only mGluR1 stimulates cAMP accumulation (Aramori and Nakanishi, 1992). Although mGluR1 increases [cAMP], has the same potency rank order of agonists that inhibit $\mathrm{Ca}^{2+}$ influx in NM neurons, and is invulnerable to L-AP3 or L-AP4, two facts indicate that a different mGluR modulates $\mathrm{Ca}^{2+}$ channels in NM. First, mGluR1 hydrolyses phosphatidylinositol-4,5-bis-phosphate, leading to an increase in PKC activity and $\left[\mathrm{Ca}^{2+}\right]_{i}$ (liberated from internal stores). Neither PKC nor an increase in $\left[\mathrm{Ca}^{2+}\right]_{i}$ were required to inhibit $\mathrm{Ca}^{2+}$ influx. Secondly, the concentration of $t$-ACPD required to elevate $[\mathrm{cAMP}]_{i}$ in mGluR 1 expressing oocytes is 10 times greater than that required to stimulate IP3 formation (Aramori and Nakanishi, 1992). While products of PI hydrolysis can be generated in explants of NM exposed to less than $100 \mu \mathrm{M} t$-ACPD (Zirpel et al., 1994a), 1 mM $t$-ACPD is required to mobilize sequestered $\mathrm{Ca}^{2+}$ in NM neurons (Zirpel et al., 1994b). This concentration was not used in this study because $t$-ACPD concentrations exceeding $200 \mu \mathrm{M}$ did not attenuate voltage-dependent $\mathrm{Ca}^{2+}$ influx effectively. Glutamatergic actions also became less effective at higher concentrations (see Fig. 8R). These results suggest that two or more mGluRs may be expressed in NM neurons. One stimulates IP3 formation; the second results in an increase in cAMP. In NM, the cAMP accumulating mGluR also acts independent of $\mathrm{Ca}^{2+}$, and is antagonized by the endogenous metabolite, SOP.

An SOP-sensitive CAMP-accumulating MGluR has also been described in the hippocampus (Winder and Conn, 1993; Winder et al., 1993). It is noteworthy that lower concentrations of glutamate and $t$-ACPD are also more effective at potentiating cAMP responses in hippocampal neurons, while significantly higher concentrations of glutamate and $t$-ACPD are required to stimulate phosphoinositide hydrolysis (Winder et al., 1993). However, unlike the NM mGluR, in the hippocampus, increasing concentrations of glutamate and $t$-ACPD increases cAMP accumulation in a dose-dependent fashion. Higher concentrations of glutamate and $t$-ACPD were less effective at attenuating $\mathrm{Ca}^{2+}$ influx in NM, and presumably stimulating cAMP activity. This U-shaped dose-response relationship suggests that the NM mGluR is only active during periods when submillimolar concentrations of glutamate are in the synaptic cleft. Thus, one possible role for this $\mathrm{mGluR}$ is that it acts in conjunction with glutamate reuptake, and receptor desensitization systems, to protect the neurons from the effects of constant, low-level exposure to glutamate.

\section{mGluRs block L-channels in NM neurons}

Two types of voltage-operated calcium channel exist: $T$ channels, activated by small depolarizations, and a trio of channels, DHP-sensitive L-channels, $\omega$-CgTX-sensitive N-channels, and FTX-sensitive P-channels, activated by larger depolarizations. The following results indicate that glutamate impedes $\mathrm{Ca}^{2+}$ influx through L-channels in NM neurons. First, $\mathrm{Ca}^{2+}$ influx observed in depolarized neurons exposed to nifedipine and glutamate was identical; in either case, large $\mathrm{Ca}^{2+}$ transients were eliminated. Second, the voltage-dependent change in $\left[\mathrm{Ca}^{2+}\right]$ seen following glutamate treatment could not be further reduced by nifidipine; it was reduced to nearly basal levels by pimozide, 
a nonspecific antagonist of low voltage-activated channels. Finally, the $\mathrm{N}$-channel blocker $\omega$-CgTX did not suppress $\mathrm{KCl}$ stimulated $\mathrm{Ca}^{2+}$ influx. A test for the presence of P-channels, which may be involved in transmitter release from the auditory nerve (Jackson and Parks, 1989), was not undertaken.

The subject of neurotransmitters altering $\mathrm{Ca}^{2+}$ channel function has been extensively studied. GABA (Scott and Dolphin, 1990), acetylcholine (Bernheim et al., 1991), norepinephrine (Lipscombe et al., 1989), and serotonin (Braha et al., 1993) all inhibit VOCCs. Glutamate has recently been added to this list (Lester and Jahr, 1990; Sayer et al., 1992; Swartz and Bean, 1992; Haws et al., 1993; Sahara and Westbrook, 1993). There is widespread agreement that glutamatergic actions are regulated by a mGluR because they (1) can be duplicated by the specific mGluR agonist $t$-ACPD, (2) cannot be duplicated by KA, AMPA, or NMDA, and (3) cannot be blocked by iGluR antagonists. Identical criteria have been used to characterize glutamatergic actions on L-channels in NM neurons.

While PKC has been shown to inhibit $\mathrm{Ca}^{2+}$ currents/influx (Anwyl, 1991; Doerner and Alger, 1992; Haymes et al., 1992; Swartz, 1993; Swartz et al., 1993), PKC has not been implicated in the mGluR-mediated VOCC inhibition that has been described previously in the mammalian models (Lester and Jahr, 1990; Sayer et al., 1992; Swark and Bean, 1992; Sahara and Westbrook, 1993). In NM neurons, $\mathrm{Ca}^{2+}$-channel inhibition could be mediated by cAMP. An enhancement of whole cell $\mathrm{Ca}^{2+}$ current responses, or a potentiation of $\mathrm{Ca}^{2+}$ influx through ionotropic receptors is usually associated with cAMP or its effector, PKA (Artalejo et al., 1990; Greengard et al., 1991; Wang et al., 1991; Bleakman et al., 1992; Keller et al., 1992). PKAmediated $\mathrm{Ca}^{2+}$-channel inhibition does not appear to be unique to NM neurons, however; dopaminergic stimulation of cAMP accumulation inhibits $\mathrm{Ca}^{2+}$ channels in other systems (e.g., Liu and Lasater, 1994).

Previous studies of mGluR-mediated L-channel inhibition may have overlooked the contributions of cAMP. This is understandable because mGluR stimulation is normally associated with the liberation of sequestered $\mathrm{Ca}^{2+}$. Additionally, five of the seven cloned metabotropic receptors inhibit cAMP accumulation. Excitation of the cAMP cascade by mGluRs has only recently been reported (Goh and Ballyk, 1993; Winder and Conn, 1993; Winder et al., 1993; Musgrave et al., 1994). There is also some evidence indicating that the activation of the adenylate cyclase system by metabotropic receptors is developmentally regulated (Casabona et al., 1992).

\section{Functional significance}

In addition to inhibiting $\mathrm{N}$ - and L-channels, mGluRs also suppress excitatory postsynaptic potentials (Desai and Conn, 1991; Lovinger, 1991; Glaum et al., 1992). The combination of these actions suggests that mGluRs act presynaptically to block neurotransmission. Our results suggest that mGluRs act postsynaptically in NM. If the $\mathrm{Ca}^{2+}$ influx seen in $\mathrm{KCl}$-depolarized $\mathrm{NM}$ neurons was due to the release of neurotransmitter from auditory nerve terminals, then this influx should have been suppressed or eliminated by $\omega-\mathrm{CgTX}$. There is widespread acceptance (although it has not been directly examined in NM) that presynaptically located $\omega$-CgTX-sensitive N-type calcium channels regulate neurotransmission (see Bean, 1989, for review). $\omega$ -CgTX did not affect NM neurons' $\mathrm{Ca}^{2+}$ responses to $\mathrm{KCl}$. Furthermore, NM neurons exhibit a very high rate of spontaneous activity (Rubel and Parks, 1975; Warchol and Dallos, 1990), which is totally eliminated by removing or silencing auditory nerve input (Born et al., 1991; Lippe, 1994). Finally, glutamate has been implicated as a trophic factor for NM neurons (Hyson and Rubel, 1989). Thus, a mGluR that attenuates neurotransmission would be undesirable in NM.

In order to understand the importance of a postsynaptically located L-channel modulating mGluR, it is useful to note that NM neurons are responsible for faithfully and precisely transmitting the microsecond differences that separate the arrival of sounds. This task has been simplified by specialized auditory nerve terminations (Carr and Boudreau, 1991), called endbulbs of Held, that cover nearly $60 \%$ of the NM neuronal surface (Hackett et al., 1981; Parks, 1981; and see Rubel and Parks, 1988 for review). As a consequence of calyciferous innervation, NM neurons are capable of phase locking to frequencies between 2000 and $9000 \mathrm{~Hz}$ (Sullivan and Konishi, 1984; Warchol and Dallos, 1990). An additional consequence of calyciferous innervation is that even in the absence of stimulation, NM neurons remain active: spontaneous rates exceed $100 \mathrm{~Hz}$ (Sullivan and Konishi, 1984; Warchol and Dallos, 1990). That auditory nerve terminals release glutamate (Nemeth et al., 1983; Raman and Trussell, 1992; Zhou and Parks, 1992), which can only be removed by diffusion from the cleft [which may not occur rapidly (Trussell et al., 1993)] or by reuptake into the presynaptic terminal, places NM neurons in a potentially excitotoxic environment. In fact, it is possible that a glutamate "sink" might exist in the synaptic cleft linking NM with the auditory nerve calyx because the rate of activity is so high, and the area of the auditory nerve synapse is so great (see Trussell et al., 1993). The notion of a glutamate sink is worth some consideration when the rates of driven activity are linked with the possibility that millimolar concentrations of glutamate are expelled from individual vesicles (Clements et al., 1992). Even under the best reuptake conditions, it might be difficult to completely purge the cleft of the glutamate. Thus, the cAMP-accumulating mGluR may be activated to protect NM neurons from this ever-present concentration of glutamate that has the potential of depolarizing the neuron and allowing $\mathrm{Ca}^{2+}$ to accumulate to lethal levels.

Continuous activation of this mGluR appears to be important for NM neurons. If glutamalergic stimulation is eliminated by cochlear removal or blocking auditory nerve action potentials with TTX, NM neurons immediately initiate a cascade of events culminating in the death of $30 \%$ of the neurons (Rubel et al., 1990 , for review). In an in vitro slice preparation developed to study signals that regulate activity-controlled neuronal degeneration (Hyson and Rubel, 1989), we found that NM neurons remained viable as long as they were stimulated orthodromically. Antidromically stimulated NM neurons began to deteriorate. In light of the present results, it would be important to determinc if antidromically stimulated NM neurons remained viable in the presence of a $\mathrm{Ca}^{2+}$ channel blocker, a mGluR agonist, or an accumulator of cAMP. Thus, it appears that the essential message glutamate provides to NM neurons is conveyed through its metabotropic regulation of cAMP.

\section{References}

Abe T, Sugihara H, Nawa H, Shigemoto R, Mizuno N, Nakanishi S (1992) Molecular characterization of a novel metabotropic glutamate receptor mGluR5 coupled to inositol phosphate/Ca ${ }^{2+}$ signal transduction. J Biol Chem 267:13361-13368.

Anwyl R (1991) Modulation of vertebrate neuronal calcium channels by transmitters. Brain Res Rev 16:265-281.

Aramori I, Nakanishi S (1992) Signal transduction and pharmacolog- 
ical characteristics of a metabotropic glutamate receptor, mGluR 1 , in transfected CHO cells. Neuron 8:757-765.

Artalejo CR, Ariano MA, Perlman RL, Fox AP (1990) Activation of facilitation calcium channels in chromaffin cells by D1 dopanime receptors through a cAMP/protein kinase A-dependent mechanism. Nature 348:239-242.

Baskys A, Malenka RC (1991) Agonists at metabotropic glutamate receptors presynaptically inhibit EPSCs in neonatal rat hippocampus. J Physiol (Lond) 444:687-701.

Bean BP (1989) Classes of calcium channels. Annu Rev Physiol 51: 367-384.

Bernheim L, Beech DJ, Hille B (1991) A diffusible second messenger mediates one of the pathways coupling receptors to calcium channels in rat sympathetic neurons. Neuron 6:859-867.

Bleakman D, Rusin KI, Chard PS, Glaum SR, Miller RJ (1992) Metabotropic glutamate receptors potentiate ionotropic glutamate responses in the rat dorsal horn. Mol Pharmacol 42:192-196.

Boord RL (1969) The anatomy of the avian auditory system. Ann NY Acad Sci 167:147-155.

Born DE, Rubel EW (1988) Afferent influences on brain stem auditory nuclei of the chicken: presynaptic action potentials regulate protein synthesis in nucleus magnocellularis neurons. J Neurosci 8:901-919.

Born DE, Durham D, Rubel EW (1991) Afferent influences on brainstem auditory nuclei of the chick: nucleus magnocellularis neuronal activity following cochlea removal. Brain Res 557:37-47.

Boss V, Conn PJ (1992) Metabotropic excitatory amino acid receptor activation stimulates phospholipase D in hippocampal slices. J Neurochem 59:2340-2343.

Braha O, Edmonds B, Sacktor T, Kandel ER, Klein M (1993) The contributions of protein kinase $\mathrm{A}$ and protein kinase $\mathrm{C}$ to the actions of 5-HT on the L-type $\mathrm{Ca}^{2+}$ current of the sensory neurons in Aplysia. J Neurosci 13:1839-1851.

Carbone E, Swandulla D (1989) Neuronal calcium channels: kinetics, hlockade and modulation. Prog Biophys Mol Biol 54:31-58.

Carr CE, Boudreau RE (1991) Central projections of auditory nerve fibers in the barn owl. J Comp Neurol 314:306-318.

Casabona G, Genazzani AA, DiStefano M, Sortino MA, Nicoletti F (1992) Developmental changes in the modulation of cyclic AMP formation by the metabotropic glutamate receptor agonist $1 \mathrm{~S}, 3 \mathrm{R}-$ aminocyclopentane-1,3-dicarboxylic acid in brain slices. J Neurochem 59:1161-1163.

Chernevskaya NI, Obukhov AG, Krishtal OA (1991) NMDA receptor agonists selectively block $\mathrm{N}$-type calcium channels in hippocampal neurones. Nature 349:418-420.

Chiamulera C, Albertini P, Valerio E, Reggiani A (1992) Activation of metabotropic receptors has a neuroprotective effect in a rodent model of focal ischaemia. Eur J Pharmacol 216:335-336.

Clements JD, Lester RAJ, Tong G, Jahr CE, Westbrook GL (1992) The time course of glutamate in the synaptic cleft. Science 258:1-1501.

Collins GG (1993) Actions of agonists of metabotropic glutamate receptors on synaptic transmission and ncurotransmitter relcase in the olfactory cortex. Br J Pharmacol 108:422-430.

Desai MA, Conn PJ (1991) Excitatory effects of ACPD receptor activation in the hippocampus are mediated by direct effects of pyramidal cells and blockade of synaptic inhibition. $\mathbf{J}$ Neurophysiol 66 : 40-52.

Doerner D, Alger BE (1992) Evidence for hippocampal calcium channel regulation by PKC based on comparison of diacylglycerols and phorbol esters. Brain Res 597:30-40.

Enyeart JJ, Biagi BA, Day RN, Sheu S-S, Maurer RA (1990) Blockade of low and high threshold $\mathrm{Ca}^{2+}$ channels by diphenylbutylpiperidine antipsychotics linked to inhibition of prolactin gene expression. J Biol Chem 265:16373-16379.

Enyeart JJ, Mlinar B, Enyeart JA (1993) T-Type $\mathrm{Ca}^{2+}$ channels are required for adrenocorticotropin-stimulated cortisol production by bovine adrenal zona fasciculata cells. Mol Endocrinol 7:1031-1040.

Forsythe ID, Clements JD (1990) Presynaptic glutamate receptors depress excitatory monosynaptic transmission between mouse hippocampal neurones. J Physiol (Lond) 429:1-16.

Fox AP, Nowycky MC, Tsien RW (1987a) Kinetic and pharmacological properties distinguishing three types of calcium currents in chick sensory neurones. J Physiol (Lond) 394:149-172.

Fox AP, Nowycky MC, Tsien RW (1987b) Single-channel recordings of three types of calcium channels in chick sensory neurons. J Physiol (Lond) 394:173-200.
Glaum SR, Miller RJ (1992) Metabotropic glutamate receptors mediate excitatory transmission in the nucleus of the solitary tract. J Neurosci $12: 2251-2258$.

Glaum SR, Miller RJ (1993) Activation of metabotropic glutamate receptors produces reciprocal regulation of ionotropic glutamate and GABA responses in the nucleus of the tractus solitarius of the rat. $J$ Neurosei 13:1636-1641.

Glaum SR, Slater NT, Rossi DJ, Miller RJ (1992) Role of metabotropic glutamate (ACPD) receptors at the parallel fiber-Purkinje cell synapse. J Neurophysiol 68:1453-1462.

Goh JW, Ballyk BA (1993) A cAMP-linked metabotropic glutamate receptor in hippocampus. Neuroreport 4:454-456.

Greengard P, Jen J, Nairn AC, Steven CF (1991) Enhancement of the glutamate response by cAMP-dependent protein kinase in hippocampal neurons. Science 253:1135-1138

Grynkiewicz G, Poenie M, Tsien RY (1985) A new generation of $\mathrm{Ca}^{2+}$ indicators with greatly improved fluorescence properties. J Biol Chem $260: 3440-3450$.

Hackett JT, Jackson H, Rubel EW (1982) Synaptic excitation of the second and third order auditory neurons in the avian brain stem Neuroscience 7:1455-1469.

Hamburger V, Hamilton HL (1951) A series of normal stages in the development of the chick embryo. J Morphol 88:49-92.

Haws CM, Slesinger PA, Lansman JB (1993) Dihydropyridine- and omega-conotoxin-sensitive $\mathrm{Ca}^{2+}$ currents in cerebellar neurons: persistent block of L-type channels by a pertussis toxin-sensitive G-protein. J Neurosci 13:1148-1156.

Haymes AA, Kwan YW, Arena JP, Kass RS, Hinkle PM (1992) Activation of protein kinase $C$ reduces $L$-type calcium channel activity of GH3 pituitary cells. Am J Physiol 262:1211-1219.

Holler T, Cappel E, Klein J, Loffelholz K (1993) Glutamate activates phospholipase $\mathrm{D}$ in hippocampal slices of newborn and adult rats. $\mathrm{J}$ Neurochem 61:1569-1572.

Hyson RL, Rubel EW (1989) Transneuronal regulation of protein synthesis in the brain stem auditory system of the chick requires synaptic activation. J Neurosci 9:2835-2845.

Jackson H, Parks TN (1989) Spider toxins: recent applications in neurobiology. Annu Rev Neurosei 12:405-415.

Jhaveri S, Morest DK (1982) Sequential alteration of neuronal architecture in nucleus magnocellularis of the developing chicken: a Golgi study. Neuroscience 7:837-853.

Keller BU, Hollmann M, Heinemann S, Konnerth A (1992) Calcium influx through subunits GluR1/GluR3 of kainate/AMPA receptor channels is regulated by cAMP dependent protein kinase. EMBO J 11:891-896.

Kelso SR, Nelson TE, Leonard JP (1992) Protein kinase C-mediated enhancement of NMDA currents by metabotropic glutamate receptors in Xenopus oocytes. J Physiol (Lond) 448:705-718.

Kinney GA, Slater NT (1993) Potentiation of NMDA receptor-mediated transmission in turtle cerebellar granule cells by activation of metabotropic glutamate receptors. J Neurophysiol 69:585-594.

Lester RA, Jahr CE (1990) Quisqualate receptor-mediated depression of calcium currents in hippocampal neurons. Neuron 4:741-749.

Lippe WR (1994) Rhythmic spontaneous activity in the developing avian auditory system. J Neurosci 14:1486-1495.

Lipscombe D, Kongsannul S, Tsein RW (1989) Alpha-adrenergic inhibition of sympathetic neurotransmitter release mediated by modulation of N-type calcium-channel gating. Nature 340:639-642.

Liu Y, Lasater EM (1994) Calcium currents in turtle retinal ganglion cells II. Dopamine modulation via a cyclic AMP-dependent mechanism. J Neurophysiol 71:743-752.

Lovinger DM (1991) Trans-1-Aminocyclopentane-1,3-dicarboxylic acid $(t$-ACPD) decreases synaptic excitation in rat striatal slices through a presynaptic action. Neurosci Lett 129:17-21.

Masu M, Tanabe Y, Tsuchida K, Shigemoto R, Nakanishi S (1991) Sequence and expression of a metabotropic glutamate receptor. Nature 349:760-765.

Musgrave M, Madigan MA, Bennett BM, Goh JW (1994) Stimulation of postsynaptic and inhibition of presynaptic adenylate cyclase activity by metabotropic glutamate receptor activation. J Neurochem 62: 2316-2324.

Nakajima Y, Iwakabe H, Akazawa C, Nawa H, Shigemoto R, Mizuno $N$, Nakanishi S (1993) Molecular characterization of a novel retinal metabotropic glutamate receptor mGluR6 with a high agonist selec- 
tivity for L-2-amino-phosphonobutyrate. J Biol Chem 268:1186811873.

Nemeth EF, Jackson H, Parks TN (1983) Pharmacological evidence for synaptic transmission mediated by non- $N$-methyl-D-aspartate receptors in the avian cochlear nucleus. Neurosci Lett 40:39-44.

Nicoletti F, Wroblewski JT, Iadarola MJ, Costa E (1986) Serine-Ophosphate, an endogenous metabolite, inhibits the stimulation of inositol phospholipid hydrolysis elicited by ibotenic acid in rat hippocampal slices. Neuropharmacology 25:335-338.

Nistri A, Cheubini E (1991) Depression of a sustained calcium current by kainate in rat hippocampal neurones in vitro. J Physiol (Lond) 435:465-481.

Nowycky MC, Fox AP, Tsien RW (1985) Three types of neuronal calcium channel with different calcium agonist sensitivity. Nature 316:440-443.

Okamoto N, Hori S, Akazawa C, Hayashi Y, Shigemoto R, Mizuno N, Nakanishi S (1994) Molecular characterization of a new metabotropic glutamate receptor mGluR7 coupled to inhibitory cyclic AMP signal transduction. J Biol Chem 269:1231-1236.

Opitz T, Reymann KG (1993) (1S, 3R)-ACPD protects synaptic transmission from hypoxia in hippocampal slices. Neuropharmacology 32 : $103-104$

Parks TN (1981) Morphology of axosomatic endings in an avian cochlear nucleus: nucleus magnocellularis of the chicken. J Comp Neurol 203:425-440

Parks TN, Rubel EW (1978) Organization and development of the brain stem auditory nuclei of the chicken: primary afferent projections. J Comp Neurol 180:439-448.

Pasic TR, Rubel EW (1989) Rapid changes in cochlear nucleus cell size following blockade of auditory nerve electrical activity in gerbils. J Comp Neurol 283:474-480.

Pizzi M, Fallacara C, Arrighi V, Memo M, Spano PF (1993) Attenuation of excitatory amino acid toxicity by metabotropic glutamate receptor agonists and aniracetam in primary cultures of cerebellar granule cells. J Neurochem 61:683-689.

Raman IM, Trussell LO (1992) The kinetics of the response to glutamate and kainate in neurons of the avian cochlear nucleus. Neuron 9:173-186.

Rubel EW, Parks TN (1975) Organization and development of brain stem auditory nuclei of the chicken: tonotopic organization of $\mathbf{n}$. mag nocellularis and $n$. laminaris. J Comp Neurol 164:411-433.

Rubel EW, Parks TN (1988) Organization and development of the avian brainstem auditory system. In: Auditory function (Edelman GM, Gall WE, Cowan WM, eds), pp 3-92. New York: Wiley.

Rubel EW, Hyson RL, Durham D (1990) Afferent regulation of neurons in the brain stem auditory system. J Neurobiol 21:169-196.

Sahara Y, Westbrook GL (1993) Modulation of calcium currents by a metabotropic glutamate receptor involves fast and slow kinetic components in cultured hippocampal neurons. J Neurosci 13:3041-3050.

Sayer RJ, Scwindt PC, Crill WE (1992) Metabotropic glutamate receptor-mediated suppression of L-type calcium current in acutely isolated neocortical neurons. J Neurophysiol 68:833-842.

Schoepp DD, Conn PJ (1993) Metabotropic glutamate receptors in brain function and pathology. Trends Pharmacol 14:13-20.

Schoepp DD, Johnson BG (1989) Inhibition of excitatory amino acid stimulated phosphoinositide hydrolysis in neonatal rat hippocampus by 2-amino-3-phosphopropionic acid. J Neurochem 53:1865-1870.

Schoepp DD, Johnson BG (1993) Pharmacology of metabotropic glutamate inhibition of cyclic AMP formation in the adult rat hippocampus. Neurochem Int 22:277-283.

Schoepp DD, Johnson BG, Smith ECR, McQuaid LA (1990) Stereoselectivity and mode of inhibition of phosphoinositide-coupled excitatory amino acid receptors by 2-amino-3-phosphoproprionic acid. Mol Pharmacol 38:222-228.

Schoepp DD, Johnson BG, Monn JA (1992) Inhibition of cyclic AMP formation by a selective metabotropic glutamate receptor agonist. $J$ Neurochem 58:1184-1186.
Scott RH, Dolphin AC (1990) Voltage-dependent modulation of rat sensory neurone calcium channel currents by $\mathrm{G}$ protein activation: effect of a dihydropyridine antagonist. Br J Pharmacol 99:629-630.

Sher E, Biancardi E, Passafaro M, Clementi F (1991) Physiopathology of neuronal voltage-operated calcium channels. FASEB J 5:26772683

Sugiyama H, Ito I, Watanabe M (1989) Glutamate receptor subtypes may be classified into two major categories: a study on Xenopus oocytes injected with rat brain mRNA. Neuron 3:129-132.

Sullivan WE, Konishi M (1984) Segregation of stimulus phase and intensity coding in the cochlear nucleus of the barn owl. J Neurosci 4:1787-1799.

Swartz KJ (1993) Modulation of $\mathrm{Ca}^{2+}$ channels by protein kinase $\mathrm{C}$ in rat central and peripheral neurons: disruption of $G$ protein-mediated inhibition. Neuron 11:305-320.

Swartz KJ, Bean BP (1992) Inhibition of calcium channels in rat CA3 pyramidal neurons by a metabotropic glutamate receptor. $\mathrm{J}$ Neurosci 12:4358-4371.

Swartz KJ, Merritt A, Bean BP, Lovinger DM (1993) PKC modulates glutamate receptor inhibition of $\mathrm{Ca}^{2+}$ channels and synaptic transmission. Nature 361:165-168.

Tanabe S, Ito I, Sugiyama H (1991) Possible heterogeneity of metabotropic glutamate receptors induced in Xenopus oocytes by rat brain mRNA. Neurosci Res 10:71-77.

Tanabe Y, Masayuki M, Ishii T, Shigemoto R, Nakanishi S (1992) A family of metabotropic glutamate receptors. Neuron 8:169-179.

Tanabe Y, Nomura A, Masayuki M, Shigemoto R, Mizuno N, Nakanishi S (1993) Signal transduction, pharmacological properties, and expression patterns of two rat metabotropic glutamate receptors, $m$ GluR3 and mGluR4. J Neurosci 13:1372-1378.

Tietje KM, Nathanson NM (1991) Embryonic chick heart express mulliple muscarinic acetylcholine receptor subtypes. J Biol Chem 266 : $17382-17387$

Tietje KM, Goldman PS, Nathanson NM (1990) Cloning and functional analysis of a gene encoding a novel muscarinic acetylcholine receptor expressed in chick heart and brain. J Biol Chem 265:2828 2834.

Trombley PQ, Westbrook GL (1992) L-AP4 inhibits calcium currents and synaptic transmission via a $\mathrm{G}$-protein-coupled glutamate receptor J Neurosci 12:2043-2050.

Trussell LO, Zhang S, Raman IM (1993) Desensitization of AMPA receptors upon multiquantal neurotransmitter release. Neuron 10 : 1185-1196.

Wang L-Y, Salter MW, MacDonald JF (1991) Regulation of kainate receptors by cAMP-dependent protein kinase and phosphatases. Science 253:1132-1135

Warchol ME, Dallos P (1990) Neural coding in the chick cochlear mucleus. J Comp Neurol 166:721-734.

Winder DG, Conn CJ (1993) Activation of metabotropic glutamate receptors increases cAMP accumulation in hippocampus by potentiating responses to endogenous adenosine. J Neurosci 13:38-44.

Winder DG, Smith T, Conn PJ (1993) Pharmacological differentiation of metabotropic glutamate receptors coupled to potentiation of cyclic adenosine monophosphate responses and phosphoinositide hydrolysis. J Pharmacol Exp Ther 266:518-525.

Zeilhofer HU, Müller TH, Swandulla D (1993) Inhibition of high voltage-activated calcium currents by L-glutamate receptor-mediated calcium influx. Neuron 10:879-887.

Zhou N, Parks TN (1992) Developmental changes in the effects of drugs acting at NMDA or non-NMDA receptors on synaptic transmission in the chick cochlear nucleus (nuc. magnocellularis). Dev Brain Res 67:145-152.

Zirpel L, Nathanson NM, Rubel EW, Hyson RL (1994a) Glutamatestimulated phosphatidylinositol metabolism in the avian cochlear nucleus. Neurosci Lett 168:163-166.

Zirpel L, Lachica EA, Rubel EW (1994b) Activation of a metabotropic glutamate receptor increase intracellular calcium concentrations in neurons of the avian cochlear nucleus. J Neurosci, in press. 